\title{
Underclass i kultura ubóstwa w badaniach nad rozwojem kompetencji moralnych i społecznych w środowiskach ludzi ubogich
}

\author{
Karolina Kowalewska \\ (Spark Academy w Poznaniu, kowalewska.km@gmail.com)
}

\begin{abstract}
Wstęp
Liczba perspektyw poznawczych proponujących różne ujęcia zjawiska ubóstwa jest imponująca, i to zarówno na gruncie filozofii społecznej, jak i socjologii, nauk ekonomicznych oraz politycznych. Perspektywy te uwzględniają elementy wyróżniane przez badaczy jako relewantne z uwagi na możliwość zdefiniowania pojęcia ubóstwa. Badacze i teoretycy rozważają bowiem odnośne pojęcie, mając na względzie takie aspekty zjawiska ubóstwa jak jego skutki, przyczyny, cechy charakterystyczne, skalę występowania oraz to, czy ma ono indywidualny, zbiorowy, bądź grupowy (obejmujący wzajemne powiązania, np. międzypokoleniowe powielanie wzorców życia i zachowania) charakter. Wśród badaczy nie ma zgody co do jednego ścisłego wyznacznika - bądź zestawu wyznaczników - które można by uznać za konstytutywne dla ubóstwa, ani też co do tego, jakie znamiona tego zjawiska uznać można za jego cechy istotowe, dystynktywne, odróżniające je od innych zjawisk. I tak też mamy do czynienia z teoriami w ujęciu absolutnym, relatywny, wielowymiarowym, próbami ujęcia ubóstwa jako brak zdolności do funkcjonowania (Sen), łączeniem zjawiska ubóstwa z marginalizacją i wkluczeniem. Prezentowane są różne nurty, jak kulturowy wiążący ubóstwo ze specyficzną subkulturą, często przejawami patologii i eksponujący mechanizm dziedziczenia nędzy; nurt liberalny, w którym źródło ubóstwa upatrywane jest w nieskrępowanych działaniach mechanizmów rynkowych czy nurt strukturalny, koncentrujący się głównie na problemach stratyfikacji społecznej, jako główny czynnik prowadzący do ubóstwa wskazując zajmowanie niższych warstwy społecznych, które blokuje i zamyka możliwości rozwoju.

Przy tak licznych sposobach konceptualizacji problemu ubóstwa, różnicach w metodologii, wynikach badawczych, definicjach i sposobie określaniu jego granic (mających wpływ na charakter i liczebność jednostek, które obejmuje kategoria ubogich),
\end{abstract}


podejmując badania zjawiska nieuchronny jest wybór ujęcia, które pozwoli zdefiniować grupę bądź kategorię osób, będącą podstawą dla planowanych analiz. W zależności od tego, czy za główną przyczynę ubóstwa przyjmiemy czynniki subiektywne (alkoholizm, niewystarczający wysiłek własny, uzależnienie od zasiłków, zachowania patologiczneitp.), czynniki losowe (np. skutki choroby, wypadków, rozwodów, klęsk żywiołowych), czy też czynniki strukturalne związane z sytuacją gospodarczą, społeczną i polityczną (brak ofert pracy, niskie dochody, silna polaryzacja dochodów, wysokie ceny, etc.), wraz ze zmianą tych kryteriów zmieni się wydatnie charakterystyka i wielkość grup kwalifikowanych jako ubogie.

Ubóstwo i związana z nim marginalizacja separują. Separacja ma zaś przeważanie charakter funkcjonalny (upośledzający funkcjonowanie człowieka), jednakże, jak pokazują badania przeprowadzone na polskich obszarach popegeerowskich, może również chodzić o separację przestrzenną, prowincjonalizację i gettoizację, co bezpośrednio przyczynia się do powstawania swoistych środowisk, ze specyficznymi kulturami, różniącymi się względem kultury głównego nurtu. Życie w środowisku wyizolowanym ogranicza możliwości rozwojowe (np. rozwój kompetencji moralno-społecznych wymagających zróżnicowanego treningu społecznego), sprzyja reprodukcji zachowań i czynników utrwalających tę sytuację, co z kolei wzmacnia mechanizm międzypokoleniowego przekazu i dziedziczenia zarówno ubóstwa, jak i wykluczenia społecznego.

W tej pracy podejmujemy próbę zanalizowania kategorii underclass oraz kultury ubóstwa, jako specyficznych paradygmatów w badaniach nad ubóstwem. Chcemy ukazać je, jako teorie, które są pomocne w analizowaniu zależności między specyfiką warunków, w jakich żyjąi rozwijają się ludzie, a wpływem na posiadanie, bądź nieposiadanie stosownych kompetencji moralnych i społecznych warunkujących skuteczne funkcjonowanie we współczesnym demokratycznym społeczeństwie opartym na wiedzy. Chodzi zatem o takie teorie, które najlepiej uwypuklałaby specyfikę stanu długotrwałego ubóstwa, jak również swoistą kulturowq odmienność reprodukowaną pokoleniowo. Teoriami, które skupiają uwagę badawczą na tych aspektach są właśnie: teoria kultury ubóstwa i teoria underclass.

Oba pojęcia „skażone są” pejoratywnym wydźwiękiem, który nadały im dyskusy polityczne $\mathrm{w}$ wielu krajach, marginalizując tym samym ich rolę $\mathrm{w}$ obszarze badań naukowych. Celem tej pracy jest wskazanie na wartościowe, z punktu widzenia badacza ubóstwa, elementy kategorii underclass oraz kultury ubóstwa. Przede wszystkim zważywszy na fakt, że rozszerzają one konceptualny zakres pojęcia biedy głównie w zakresie uwypuklenia pozadochodowego aspektu ubóstwa, dzięki czemu możliwe jest zarysowanie rzeczywistej sytuacji i szans jednostki, ze szczególnym uwzględnieniem szerokiego spektrum deprywacji, zwłaszcza w kontekście pozamaterialnego, psychospołecznego wymiaru zjawiska, uwzględniającego chociażby brak stosownych kompetencji kluczowych dla skutecznego funkcjonowania w sferze ekonomicznej, społecznej czy publicznej. Takie podejście pozwala spojrzeć na problem ubóstwa jako 
wypływający nie tylko z uwarunkowań strukturalnych czy indywidualnych predyspozycji, postaw lub działań jednostki, ale także jako na zjawisko zakorzenione w kontekście, środowisku życiowym i kulturowym. To zaś daje możliwość ukazania ubóstwo jako swoistego rodzaju środowisko życia jednostek, które poprzez pewne specyficzne elementy oddziałuje na ich rozwój i sposób funkcjonowania, tym samym na możliwości zdobycia przez nie stosownych kompetencji społecznych czy kompetencji moralnych warunkujących sukces życiowy jednostek pojmowany jako wyzwolenie się z kręgu ubóstwa.

Wybór koncepcji dla badań zjawiska ubóstwa jest istotny również z praktycznego punktu widzenia, przekłada się to bezpośrednio na sposób tworzenia programów przeciwdziałania zjawisku. Wybierając koncepcje podkreślające znaczenie czynników z zakresu deprywacji potrzeb pozaekonomicznych, uzyskujemy wyniki badań, które pozwalają tworzyć programy pomocowe o szerokim spektrum oddziaływania. Nie koncentrujemy się wyłącznie na poprawie materialnego aspektu życia jednostki. Zachodzi tu znacząca reorientacja ukierunkowania zainteresowań poznawczych, działań interwencyjno-prewencyjnych oraz naprawczych. W ramach odnotowanej tutaj tendencji programy przeciwdziałania zjawisku ubóstwa mają przyczyniać się do poprawy jakości zdrowia, poziomu wykształcenia (w tym - wyposażenia w kompetencje kluczowe), a także do podnoszenia efektywności działań organizacji pomocowych i społecznych.

\section{Zarys zagadnienia}

Po raz pierwszy pojęcia underclass (podklasa) użył w latch 60-tych XX w. szwedzki socjo-ekonomista Gunnar Myrdal (1963). Posłużyło ono do opisu sytuacji społecznokulturowej mniejszości etnicznych i rasowych zamieszkujących getta na obrzeżach wielkich amerykańskich miast w czasie długotrwałego bezrobocia i szerzącej się biedy, w okresie transformacji społeczeństwa amerykańskiego. Do underclass Myrdal zaliczył jednostki charakteryzujące się deprywacją warunków materialnych (spowodowanych głównie długotrwałym bezrobociem, które z kolei wynikało ze zmian strukturalnych i technologicznych na rynku pracy, jakim nie byli w stanie sprostać ludzie z klas niższych) oraz zmarginalizowane w obszarze stosunków społecznych. Marginalizacja ta dotyczyła głównie niskiego poziomu edukacji ${ }^{1}$ i dyskryminacji rasowej ${ }^{2}$. Pojęcie to zyskało na popularności wśród amerykańskich badaczy społecznych ${ }^{3}$ i już w roku 1962

1 Powiązania między długotrwałym ubóstwem a niskim poziomem wykształcenia wykazali $\mathrm{w}$ badaniach m. in. R. Erol i I. Sawhill (1988, 316-325; por. A. Buckingham 1999; Domański 2002).

$2 \mathrm{~W}$ przypadku Polski dyskryminacja rasowa nie jest zjawiskiem istotnym statystycznie dla zjawiska underclass, ze względu na niski udział mniejszości etnicznych w całej populacji kraju. Według danych z Narodowego Spisu Powszechnego Ludności i Mieszkań 2011 roku (GUS 2015), w Polsce udział mniejszości etnicznych wśród dorosłej ludności wyniósł zaledwie 3,81\%. Wskaźniki te mogą jednak ulec zmianie w nadchodzących dekadach, zależnie od polskiej polityki migracyjnej.

3 Prawdziwą międzynarodową popularność pojęcie underclass zyskało po publikacji serii artykułów zamieszczonych w magazynie „The Times”. Znaczącą rolę odegrały wówczas artykuły 
Michael Harrington wydał wpływową książkę pt. The Other America. Poverty in United States, w której charakteryzował underclass jako grupę składającą się z osób starszych, niewykwalifikowanych pracowników, samotnych matek etc. skazanych na wykluczenie bez względu na to, jak silny byłby wzrost gospodarczy, a to z racji algorytmu dystrybucji dochodów (Harrington 1962, 14-18). Po ukazaniu się publikacji Harringtona koncepcja zaczęła się silnie rozwijać, wypływały coraz to nowsze ujęcia underclass. Klasycy badań nad kategorią podklasy charakteryzowali ją głównie poprzez wyróżnienie szeregu cech, jakimi odznaczać się mają członkowie tej grupy.

Harrington do deprywacji materialnej i marginalizacji wskazanej przez Myrdala, jako czynnik warunkujący pojawienie się underclass dołożył aspekt dziedziczenia biedy. Dziedziczenie to odbywa się nie tylko na poziomie materialnym, ale przede wszystkim jest to dziedziczenie pozycji, strategii życiowych, stylu życia, kultury i swoistego etosu, co wykazał w swych badaniach Greg Duncan (Duncan 1997, 1998). .„Tak skonfigurowane środowisko uczy, że nie warto się kształcić, że wystarczy utrzymywać się z dorywczych prac i zasiłków z pomocy społecznej. Dzieciom przekazuje się postawę bierności, izolacji od wpływu kultury dominującej" (Zabielska 2007, 73).

Ch. Murray w aspekcie dziedziczenia biedy zwrócił uwagę na rolę uzależnienia od pomocy społecznej. Zasiłki nazywał Murray „mylącymi zachętami”, oceniając je jako demoralizujące, gdyż stają się one źródłem dochodów niepowiązanych z pracą, co zostało przez członków underclass przyjęte jako wygodna strategia życiowa. Znaczy to, że zasiłek niejest pobierany z konieczności, lecz z wyboru. Styl życia osoby bezrobotnej utrzymywanej przez państwo staje się stylem życia przekazywanym następnym pokoleniom. Takim strategiom życiowym towarzyszy załamanie się tradycyjnej moralności i zastąpienie jej przez kontrkulturę deprecjonującą i odrzucającą społeczną wartość ludzkiej pracy (Murray 2001). „Uzależnienie od pomocy społecznej, wywołuje silną potrzebę wsparcia z zewnątrz i powoduje niesamodzielność jednostek z niej korzystających, niszcząc tym samym inicjatywę do poszukiwania alternatywnego sposobu pozyskiwania środków do życia. W dłuższej perspektywie przyczynia się do stopniowej demoralizacji i całkowitego odrzucenia wartości pracy, co w efekcie może przerodzić się w tworzenie kulturowego wymiaru biedy" (Karwacki 2006, 91-92). Uzależnienie od pomocy społecznej wynika m.in. z faktu, że niskie kwalifikacje zawodowe biednych nie pozwalają na znalezienie

takich badaczy biedy jak W. J. Wilson, R. Aponte, L. Liebermann i K. Auletta. Dzięki wprowadzeniu owego pojęcia do świadomości publicznej zaczęto się nim częściej posługiwać w badaniach i dyskusjach nad problemami społecznymi w USA. Sytuacja osób z ubogich dzielnic wielkich miast zyskała na znaczeniu, a zjawisko ubóstwa otrzymało nowe oblicze. Obok klasycznych ujęć i wyznaczników biedy takich jak bezdomność, inwalidztwo i choroba, pojawiły się nowe zjawiska, tj. chroniczne bezrobocie, zorganizowana przestępczość, uzależnienia i strukturalna izolacja w postaci miejskich gett zamieszkanych głównie przez mniejszości etniczne i rasowe. Problem underclass przestał być dla polityków w USA problemem marginalnym, gdyż rozrastająca się underclass, zdominowana przez mniejszości etniczne i rasowe, nie wynikała jedynie z czynnej dyskryminacji, o czym świadczyło powstanie „czarnej” klasy średniej, ale kształtowała się w oparciu o czynniki ekonomiczne i szereg elementów kształtujących się jako efekt deprywacji majątkowej i marginalizacji społecznej tych ludzi. Podjęto próby znalezienia rozwiązania problemu podklasy, co zaowocowało wnikliwą analizą zjawiska i wyłonieniem się jego dwóch różnych ujęć, tj. kulturowego i strukturalnego. 
stałego zatrudnienia, bądź też zatrudnienia satysfakcjonującego pod kątem samooceny, prestiżu, a przede wszystkim zarobków, które mogłoby konkurować z wysokością otrzymywanych zasiłków. Łatwiej jest dostosowywać swój sposób funkcjonowania do wymogów programów pomocowych poprzez np. większą liczbę nieślubnych dzieci i monopaternalizm (pomoc częściej udzielana jest matkom samotnie wychowującym dzieci), niż podjąć wysiłek zabiegania o pracę zarobkową i utrzymania jej. Taka strategia życiowa wpływa jednak na dobór wartości, norm i postaw, jakie przekazywane są dzieciom, szczególnie w odniesieniu do modelu rodziny, znaczenia i wartości pracy oraz poszanowania własności.

Ralph Dahrendorf, sięgający m.in. do badań Wilsona, Nathana i Auletty, w „katalogu” cech członków underclass również wymienia brak klasyfikacji zawodowych, słabą więź ze środowiskami ludzi pracujących oraz bezrobocie. Poza czynnikami związanymi z pracą zarobkową, wskazuje na fakt, że wielu członków underclass należy do mniejszości etnicznych, żyje w niekompletnych rodzinach oraz wykazuje skłonności do zachowań aberracyjnych, czyli nadużywania alkoholu, uzależnienia od narkotyków czy działań przestępczych, jak również zależności od opieki społecznej, najczęściej trwałej, kilkupokoleniowej (Dahrendorf 1993, 237). Jako istotny czynnik warunkujący kwalifikację danej grupy ubogich do podklasy Dahrendorf wymienia izolację społeczną ${ }^{4}$ (ubodzy są wykluczani z istotnych obszarów życia społecznego) oraz ograniczenie kontaktów społecznych do środowiska lokalnego (Rainwater 1967, 2006).

Dahrendorf był sceptyczny wobec pojęcia izolacji przestrzennej jako wyróżnika podklasy, jednak część badaczy, zwłaszcza amerykańskich, włącza do analizy podklasy ten właśnie wymiar, wyodrębniając dwa główne kryteria: (1) kumulację ubóstwa (bliskość przestrzenną, wspólne zamieszkiwanie osób w podobnej sytuacji) oraz (2) izolację, tj. przestrzenną segregację tych środowisk. W przypadku klasycznego ujęcia underclass mowa jest głównie o wielkomiejskich gettach, charakterystycznych dla państw zachodnich, z wysokim odsetkiem imigrantów sprawiającą, że gettoizacja kojarzona jest zazwyczaj z czynnikami rasowo-etnicznymi. W krajach homogenicznych pod względem rasowym i etnicznym segregacja przestrzenna ubogich wynika głównie z przyczyn strukturalno-systemowych. W Polsce są to np. środowiska popegeerowskie.

Mimo iż nie ma zgody co do kwestii przestrzennej izolacji underclass, to już pauperyzacja środowiska życia osób trwale ubogich jest wskazywana przez większość badaczy, jako cecha istotna. To właśnie życie w spauperyzowanym środowisku w

4 Dahrendorf w oparciu o szereg badań empirycznych prowadzonych w USA i krajach europejskich poddaje $\mathrm{w}$ wątpliwość kategorię izolacji przestrzennej jako klasowego wyróżnika underclass. Zgadza się on jednak z R. Nathanem, który z kolei zwraca uwagę na to, iż swoista silna bariera w strefie uprawnień, która skutecznie izolują grupę trwale ubogich od reszty społeczeństwa, wystarczy do tego, by mówić o nich jako o klasie społecznej. Istniejące formalnie uprawnienia często obarczone są formalnymi ograniczeniami w dostępie dla osób trwale ubogich Jednak ich prawdziwa niedostępność wynika głównie z form materialnej realizacji owych uprawnień przez organy i instytucje państwa, ale również z powodu braku możliwości (np. brak zdolności, wiedzy) do skorzystania z nich przez samych zainteresowanych, np. zagwarantowany jest powszechny dostęp do szkół, ale uczniowie opuszczają je bez podstawowych kompetencji takich jak zdolność czytania i pisania. 
dużym stopniu odpowiada za izolację (tak społeczną, jak i autoizolację) i wykształcenie się specyficznego stylu życia oraz strategii życiowych, nieobserwowanych w innych środowiskach. Izolacyjny charakter underclass prowadzi, zdaniem Dahrendorfa, do „jawnej niezdolności lub niechęci wielu ludzi do przyswajania sobie wartości otaczającego ich społeczeństwa" (Dahrendorf 1993, 243). Skutkuje to ograniczeniem kontaktu z przedstawicielami innych grup, co jeszcze silniej izoluje osoby ubogie i pogłębia ich odrębność. Członków underclass w większości nie interesują bieżące sprawy społeczne czy polityczne, są wyalienowani z obiegu informacji i dyskursów społecznych, wyrzuceni poza główny, uporządkowany strukturalnie i uregulowany nurt życia społecznego.

Deprywacja materialna i marginalizacja wzajemnie na siebie oddziałują. Jak zauważają William Julius Wilson (1990) i David Smith (1992), marginalizacja w dziedzinie kultury, postaw i stylu życia jest wynikiem ekskluzji, zepchnięcia tej grupy poza obwód spraw, którymi żyje większość społeczeństwa. Wilson dowodzi, że ci członkowie grup mniejszościowych, którzy zamieszkują tereny gett, znajdują się $\mathrm{w}$ stanie głęboko strukturalnie uwarunkowanej izolacji społecznej. Charakterystyczny dla tej grupy system zachowań jest wyrazem procesu adaptacji do warunków silnie ograniczających możliwości tych ludzi względem reszty społeczeństwa. Oddziałuje na nich „efekt koncentracji”, który sprawia, że granice między członkami podklasy a resztą społeczeństwa coraz silniej się usztywniają (Wilson 1989). Owa izolacja jako wyróżnik dla trwale ubogich, podkreślana również przez innych badaczy underclass, jest jednym z kluczowych elementów ograniczających możliwości rozwojowe w obszarze kompetencji, zwłaszcza kompetencji społecznych, ale również wysokorozwiniętych kompetencji moralnych, których rozwój determinowany jest poprzez różnorodność, ilość oraz jakość interakcji społecznych oraz tzw. treningów społecznych (Argyle 2002; Makowska 2012; Kohlberg 1964, 1976)

Joan Gordon, wykorzystując kategorię Mardala do swoich badań nad jakością życia nowojorskich rodzin, w pracy The Poor of Harlem: Social Functioning in the Underclass (1965) jako pierwsza zwróciła uwagę na normatywne deficyty wśród badanych, które uznałazakolejnązcechwyróżniającychunderclass.Silniejkwestiędeficytównormatywnych podkreślali zwolennicy nurtu kulturowego. Sporo uwagi kwestii deficytów normatywnych poświęcił w późniejszym okresie również William J. Wilson (zwolennik podejścia syntetycznego do underclass). Opierając się na licznych badaniach przeprowadzonych na terenie ubogich dzielnic, Wilson wskazał na zwiększoną częstotliwość występowania w nich takich zjawisk jak: niezaliczanie klas w szkole, ciąże nastolatków, urodzenia pozamałżeńskie, brak starań o znalezienie pracy, zachowania dewiacyjne, odejście od norm preferowanych przez resztę społeczeństwa, dewastacja budynków (Wilson 1987). Jego zdaniem, kumulacja tych zachowań w danym środowisku sprawia, że wśród osób trwale ubogich zaczynają dominować normy postrzegane przez resztę społeczeństwa jako dewiacyjne, pojawia się też zjawisko przekształcania mainstreamowych norm społecznych we własne poprzez dostosowanie ich do wewnętrznych warunków panujących w ubogim środowisku. W efekcie stają się one w opinii reszty społeczeństwa 
alternatywnymi i zgoła dewiacyjnymi wariantami norm z głównego nurtu. To zaś sprawia, że grupy spoza ubogiego obszaru zaczynają marginalizować to środowisko, np. poprzez dyskryminowanie osób z danego obszaru przy rekrutacjach zawodowych, poprzez wygłaszanie negatywnych opinii o mieszkańcach danej dzielnicy, unikanie tych miejsc itp. (Wilson 1987). W taki sposób obszar zamieszkiwany przez dużą liczbę osób ubogich staje się homogeniczny i zamknięty jednocześnie To zaś zaczyna oddziaływać na zachowanie i postawy prezentowane przez jej mieszkańców, na tworzone w tym obszarze normy czy preferowany styl życia. Pojawia się tym samym znaczna liczba osób przejawiających zachowania i reguły praktyczne odbiegające od prezentowanych przez większość społeczeństwa (Wilson 1991).

Środowisko długotrwałej biedy ma szczególnie negatywny wpływ na dzieci, których procesy rozwojowe i socjalizacja przebiegają w wyizolowanych i obarczonych wieloma deficytami warunkach. Zdaniem Wilsona, pauperyzacja i izolacja sprawiają, że alternatywne względem głównego nurtu społecznego wzory zachowań stają się podstawą procesu socjalizacji i stanowią fundament tworzenia własnego „podkulturowego” świata. Nie są one oczywiście przez członków grup trwale ubogich postrzegane jako dewiacyjne, dlatego rozpowszechnia się je i przekazuje następnym pokoleniom jako naturalne wzory zachowań. Wilson określa je jako normy i wartości powstające w wyniku wielokrotnych transmisji racjonalnych postaw adaptacyjnych, wymuszanych poprzez konkretne sytuacje powstające w wyniku określonych zmian strukturalnych ${ }^{5}$. Im są wyraźniejsze i dłużej przekazywane, tym silniej wpływają na izolowanie się osób ubogich od reszty społeczności. Izolacja tajestwzmacniana poprzez kolejne symptomatyczne dlaśrodowiska wzory zachowań, jak np. ten opisany przez Wilsona w The Truly Disadvantaged. Powiada on, że kobiety z ubogich środowisk mają tendencję do wybierania partnerów z niskim wykształceniem, dotkniętych bezrobociem, należących do grupy wysokiego ryzyka, bądź zajmujących się nielegalnym zdobywaniem pieniędzy. Najczęściej nie wchodzą z nimi w formalne związki, lecz rodzą im dzieci. Posiadanie partnera, który nie jest w stanie zaspokoić potrzeb kobiety i jej dziecka, sprawia, że związek ten nie poprawia ich sytuacji. Odwrotnie, wzmacnia ubóstwo, ogranicza możliwości działania, popycha w stronę aplikacji norm i wzorów zachowań alternatywnych wobec reszty społeczeństwa, a także wzmacnia uzależnienie od pomocy z zewnątrz, np. od systemu pomocy społecznej. Czynniki, które ugruntowują negatywne położenie matki, wpływają również na niskie szanse życiowe jej dziecka, przez co bieda przekazywana jest z pokolenia na pokolenie (Wilson 1987, 57-93).

Od początku funkcjonowania pojęcia underclass, brak jest pełnej zgodności co do faktycznych form występowania klasy oraz rozpoznania głównej determinanty tworzenia się tej specyficznej grupy osób ubogich. W miarę tego, jak dyskusje nad zjawiskiem underclass nabierały coraz szerszego wymiaru, nastąpił rozłam na dwie odrębne struktury argumentacyjne. Przyczyn powstawania podklasy poszukiwano w ramach 
dwóch różnych nurtów: strukturalnego (akcentującego uszeregowanie ludzi ubogich na najniższym szczeblu drabiny klasowej) oraz kulturowego (wskazującego głównie na różnice we wzorach zachowań między członkami underclass a resztą społeczeństwa). Na bazie krytyki obu nurtów powstało także podejście syntetyczne, łączące elementy obu nurtów. Poniżej omówię pokrótce każde z nich.

\section{Podejście strukturalne do underclass}

Podejście strukturalne koncentruje uwagę na strukturalnych uwarunkowaniach underclass, które są odpowiedzialne za ekonomiczną deprywację członków tej grupy. $\mathrm{Na}$ arenie politycznej reprezentowane głównie przez intelektualną lewicę (partie socjaldemokratyczne w Europie i partię demokratyczną w USA). W ramach tego ujęcia jednostki traktowane są jako ofiary takich zjawisk jak wyzysk, nierówności, wykluczenie i władza. Henryk Domański w książce Ubóstwo w społeczeństwach postkomunistycznych wskazuje dwa podstawowe wyróżniki podejścia strukturalnego:

1. odwoływanie się do zestawu makrostrukturalnych czynników związanych z funkcjonowaniem gospodarki rynkowej;

2. wskazanie na relację między uwarunkowaniami strukturalnymi, będącymi immanentnym atrybutem współczesnego kapitalizmu, a zachowaniami i postawami zaliczanymi do syndromu „kultury ubóstwa” (Domański 2002, 106112).

Wyjaśnienia strukturalne na znaczeniu zyskały na przełomie lat 80-tych i 90-tych $\mathrm{XX}$ wieku, kiedy to społeczeństwa kapitalistyczne weszły $\mathrm{w}$ fazę postindustrialną, tj. „etap charakteryzujący się m.in. bezzatrudnieniowym niskim wzrostem gospodarczym, kryzysem welferstate oraz nową strukturyzacją społeczeństw, powodowaną rozszerzającymi się obszarami bezrobocia i biedy" (Grotowska-Leder 2004, 238). Domański wyróżnia cztery podstawowe strukturalne przyczyny trwałego ubóstwa. Jako pierwszą wskazuje zmienność koniunktury gospodarki kapitalistycznej oraz segmentację rynku, czyli wyodrębnienie się peryferyjnych i kluczowych sektorów na rynku pracy, w poszczególnych branżach oraz przedsiębiorstwach. Oba czynniki wpłynęły na sytuację potencjalnych kandydatów do członkostwa podklasy. Ich niski poziom wykształcenia, brak kompetencji zawodowych i społecznych, niewykształcony odpowiednio etos pracy (długotrwałe bezrobocie rodziców) spowodowały, że znalezienie stałej pracy, nawet niskopłatnej, stało się problematyczne.

Kolejna przyczyna leży w przestrzennych uwarunkowaniach procesów wyłączania jednostek z rynku pracy (zamykanie zakładów pracy w obrębie jakiegoś terytorium), w rezultacie czego tworzą się tzw. „kieszenie ubóstwa”, których wymownym przykładem w Polsce są tereny popegeerowskie. Obszary te zamieszkuje duża grupa osób wyłączonych z rynku pracy na skutek działania mechanizmów zewnętrznych, często w wyniku likwidacji dużych zakładów pracy. 
Jako ostatni czynnik determinujący trwałą biedę (zwłaszcza w Polsce) Domański wskazuje przesunięcie wytwórczości z przemysłu do usług. Zmiana ta wywarła kolosalny wpływ na strukturę zawodową, objawiającą się stopniowym zanikaniem kategorii zawodowych charakteryzujących się niską złożonością wykonywania zadań, związanych z pracą fizyczną, co wpływa na marginalizację, a w dużej mierze także na zanik zawodów niewymagających szczególnych kwalifikacji, które tradycyjnie wykonywali reprezentanci klas niższych np. górnictwo na Śląsku (Domański 2002, 107-110).

To właśnie brak realnych dochodów jest, zdaniem Dahrendorfa, podstawową barierą, która na równi z dyskryminacją społeczną i kulturową różnicuje społeczeństwa. Realne dochody są podstawą rzeczywistego korzystania z praw obywatelskich, a te, wraz ze źródłami dochodów, osoby bezrobotne wydają się tracić bezpowrotnie. Wykształcenie i dochody z pracy to dwa rodzaje zasobów uznawane za podstawowe dla życiowego powodzenia: „kwalifikacje wyznaczają bowiem szanse na rynku pracy, a zarobki są biletem wstępu do świata zasobów" (Grotowska-Leder 2004, 237). Ograniczony dostęp członków underclass do tych przestrzeni życia społecznego i gospodarczego sprawia, że ich sytuacja ulega utrwaleniu, przez co, jak twierdzi Giddens, zaczynają oni wytwarzać „kulturę ubóstwa”, która jest formą adaptacji do zmiennych warunków egzystencji i pełnienia nowej roli społecznej. „Wpływy społeczne stwarzające podklasy mają charakter strukturalny zanim staną się kulturowe, ale kiedy już działają, mogą spowodować głęboką demoralizację kulturową" (Giddens 2001, 163).

Część badaczy uważa jednak, że to element kulturowy stanowi czynnik sprawczy zjawiska underclass. Badacze ci zaliczają się do tzw. nurtu kulturowego underclass.

\section{Znamiona underclass w ujęciu kulturowym}

Perspektywa i podejście kulturowe, zwane także genetycznym, behawioralnym lub patologicznym rozwinęło się w końcu lat 70-tych XX wieku. Głównymi przedstawicielami nurtu są badacze biedy o konserwatywnych poglądach, tacy jak Charles Murray, Mickey Kaus, Lawrence Mead, Ken Auletta, w Polsce zaś Elżbieta Tarkowska i Hanna Palska. W początkowym okresie badacze z tego kręgu wprost nawiązywali do kulturowych ujęć biedy opierających się na występowaniu różnic we wzorach zachowań pomiędzy członkami underclass a resztą społeczeństwa. Różnic tych doszukiwano się głównie w uznawanych przez członków podklasy wartościach, przejawianych zachowaniach, postawach oraz mechanizmach ich kształtowania się. Kulturę underclass ujmowano w kategoriach zachowań niewłaściwych, nazywanych przez Murraya godnymi pożałowania (Murray 2001). Badacze nurtu kulturowego jednoznacznie wskazywali na demoralizację tej grupy wynikającą przede wszystkim z deficytów w sferze norm i wartości, wytwarzanych i utrwalanych poprzez specyficzne warunki życia, niemające odpowiednika w życiu innych środowisk, a także przez nadmierną i niewłaściwie organizowaną pomoc społeczną funkcjonującą w państwach rozwiniętych, która wspomaga rozwój syndromu uzależnienia 
od pomocy, funkcjonowania bez zobowiązań, braku ambicji i poczucia odpowiedzialności. Ludzie trwale ubodzy przystosowują się do warunków życia poprzez kreowanie stylu, postaw i strategii adaptacyjnych umożliwiających przeżycie, ale skutkujących takimi zjawiskami jak dezintegracja struktury rodzinnej, izolacja od reszty społeczeństwa, brak zainteresowania sprawami istotnymi dla reszty społeczeństwa, załamanie się tradycyjnej moralności, zwłaszcza w obszarze wartości ludzkiej pracy czy funkcjonowanie na pograniczu prawa (Domański 2002, 100-106).

Do underclass zaliczano osoby z grup niezasymilowanych z resztą społeczeństwa. Auletta w jednej z pierwszych monografii poświęconych underclass (1982) wyłonił cztery podstawowe grupy społeczne, które tworzą podklasę, tj. 1) ubogich, wieloletnich beneficjentów pomocy społecznej, których deprywacja materialna była wynikiem ich pasywnego podejścia do życia, lenistwa i braku aspiracji życiowych; 2) przestępców, w przeważającej części członków gangów i handlarzy narkotyków; 3) przemytników i handlarzy ulokowanych szarej strefie ${ }^{6}$; 4) nałogowych alkoholików, narkomanów, włóczęgów, bezdomnych, osoby starsze i chore (głównie psychicznie), których nie stać na leczenie i zaspokojenie podstawowych potrzeb życiowych (Auletta 1982). Klasyfikacja Auletty poddana została krytyce, szczególnie dlatego, że bezwarunkowo przypisał dane kategorie ludzi, jako przedstawicieli podklasy, co poczytywano za nieuprawnione ${ }^{7}$, jednakże pewne jego sugestie co do występowania charakterystycznych dla tych grup osób schematów behawioralnych zostały uznane za podstawowe wyznaczniki przynależności- zaczęto koncentrować uwagę na swoistych cechach i schematach działania. Można tu wskazać przede wszystkim całkowite uzależnienie potrzebujących od materialnej pomocy państwa, dużą liczbę związków o charakterze konkubinatu oraz pozamałżeńskich urodzeń, brak aktywności zawodowej zwłaszcza wśród mężczyzn oraz wysoki odsetek przestępczości. Wszystkie z wymienionych przez Aulettę czynników, a zwłaszcza uzależnienie od pomocy i brak aktywności zawodowej, sprzyjają „rozpadowi rodziny nuklearnej” i powodują „socjalizację do kontrkultury, która charakteryzuje się niską wartością ludzkiej pracy i sprzyja tworzeniu się trwałych form socjalnej zależności od państwa oraz cechuje się wysokim stopniem kryminogenności" (Murray 2001, 27).

To właśnie dziedziczenie postaw i norm przez członków podklasy jest jedną z kluczowych kategorii podejścia kulturowego do underclass. „Jest to kluczowy punkt, albowiem zakłada się, że instytucjonalizacja, czyli utrwalenie się (...) orientacji i postaw, powoduje, że zaczynają one kształtować bieg życia jednostek w postaci samodzielnego czynnika" (Murray 2001, 103). Przedmiotem transmisji międzypokoleniowej są specyficzne normy i wartości. Karwacki podkreśla, że „mamy tu do czynienia z ukształtowaną odmienną tożsamością osoby biednej od „nie-biednej” (socjalizacja w

6 Te dwie kategorie również spotkały się z silną krytyką, gdyż osoby ze świata przestępczego rzadko dotyka problem ubóstwa, a już tym bardziej ubóstwa chronicznego.

7 Najczęściej krytycznie wskazywano na grupę handlarzy narkotyków czy przemytników, których sposób funkcjonowania trudno jest porównać np. z osobami trwale bezrobotnymi i uzależnionymi od pomocy społecznej. 
warunkach/do „kultury biedy”) i poprawa warunków życia jednostek (wzrost zasobów materialnych) nie spowoduje zmian specyfiki ich świata wewnętrznego (wartości, normy, cele życiowe)" (Murray 2001, 92-93). Podejście kulturowe jest zatem powiązane $\mathrm{z}$ determinizmem kulturowym. Utrwalanie orientacji i postaw życiowych przez mechanizmy socjalizacji i reprodukcji kulturowej sprawia, że zaczynają one stanowić zewnętrzny względem jednostki czynnik determinujący jej życie w danym środowisku. Przystosowanie do życia w biedzie nabiera z czasem charakteru osobowościowego, przez co życie poza obszarem biedy zdaje się być tak wielkim wyzwaniem, że nawet zmiana uwarunkowań zewnętrznych, np. w postaci poprawy koniunktury gospodarczej, nie stanowi szansy na wydobycie się ze stanu ubóstwa.

Podsumowując, można stwierdzić, że podejście kulturowe do underclass opiera się na takich oto gruntownych założeniach:

Po pierwsze, życie w nędzy stawia ludzi w szczególnej sytuacji, niemającej odpowiednika $\mathrm{w}$ życiu innych środowisk. Po drugie, osoby funkcjonujące $\mathrm{w}$ tych specyficznych warunkach przystosowują się do trudnych warunków, wytwarzając strategie, styl i kategorię adaptacji, a także tworząc zamknięte systemy norm i wartości. Po trzecie, osoby trwale ubogie charakteryzują się niskimi kwalifikacjami zawodowymi, co obniża ich możliwości podjęcia pracy. Po czwarte, są one uzależnione od pomocy społecznej i traktują zasiłki jako formę zarobkowania. Po piąte, rezultatem tej dobrowolnej adaptacji jest formowanie się odrębnego systemu orientacji i postaw, składających się na kulturę, a w gruncie rzeczy na subkulturę ubóstwa (Domańska 2002, 102).

\section{Podejście syntetyczne do underclass}

Czołowym przedstawicielem nurtu syntetycznego w badaniach nad underclass jest William Julius Wilson. W latach 80-tych badał on powstawanie underclass $\mathrm{w}$ USA w obszarach wielkomiejskich, gdzie na skutek zmian strukturalnych, takich jak wycofywanie się przedsiębiorstw ze zdegradowanych dzielnic dużych miast, zaczęła tworzyć się podklasa. Pozostająca bez pracy, coraz silniej doświadczana skutkami deprywacji materialnej, systematycznie spychana na margines społeczny grupa zaczęła przejawiać coraz wyraźniejsze symptomy odrębności kulturowej, od negacji wartości uznawanych przez większość społeczeństwa poczynając. Wilson zaobserwował wypływ marginalizujących zmian strukturalnych na strukturę psychospołeczną grupy najsilniej dotkniętej tymi zmianami.

DlaWilsona „kulturaubóstwa” jestodpowiedziąnastrukturalneprzymusy społeczne, a także generowane przez nie (bezpośrednio lub pośrednio) ograniczenie możliwości (Wilson 1989). W rezultacie można stwierdzić, że status kulturowy członków badanych wykluczonych społeczności jest, z jednej strony, zależny od towarów, usług, umiejętności i możliwości, którymi ludzie dysponują, ale z drugiej strony, towary, usługi umiejętności i możliwości także nie są wolne od wpływu czynników kulturowych (np. rasowych), które 
zmniejszają szanse życiowe trwale ubogich społeczności. „W analizie podklasy równie istotne są predyspozycje kulturowe, wytworzone specyficzne dla pewnych zbiorowości normy, wartości, ale przede wszystkim postawy adaptacyjne do zmian strukturalnych w społeczeństwie" (Karwacki 2006, 98). Jest to rozwiązanie zrozumiałe, gdyż w świecie życia społecznego trudno jest ograniczać się do rozpatrywania wpływu jedynie wybranej grupy czynników na los jednostki (Wilson 1990). Dodatkowo należy uwzględniać specyfikę konkretnego społeczeństwa, gdyż w zależności od warunków typowych dla danej grupy, powstają charakterystyczne dla niej i symptomatyczne kryteria ubóstwa, co z kolei wpływa na kształtowanie się swoistych dla tego społeczeństwa grup underclass (Wilson jako zwolennik ujęcia relatywnego w badaniach nad ubóstwem akcentował rolę elementów specyficznych środowiska w formowaniu się podklasy i zależnych od środowiska różnic w jej funkcjonowaniu).

\section{Krytyka pojęcia underclass}

Underclass jako kategoria użyteczna $\mathrm{w}$ rozważaniach nad problemem biedy została następnie zaadaptowana w krajach europejskich i po dzień dzisiejszy stosowana jest w analizach tego zjawiska. Jednakże na Starym Kontynencie określenie underclass nabrało z czasem wydźwięku silnie pejoratywnego i emocjonalnego. Wpływ na to mieli głównie politycy, którzy poprzez błędne rozumienie czynników wyróżniających członków underclass rozpropagowali w mediach obraz grupy składającej się wyłącznie z przestępców, narkomanów i rozwiązłych kobiet w pełni odpowiadających za swoją ciężką sytuację materialną. Pojawiła się tendencja do dualistycznego zróżnicowania i demarkacji, na mocy której zarysowano ostrą linię podziału między „nami” (normalnymi) a „nimi” (zdeprawowanymi). Ludzie zmarginalizowani zaczęli być traktowani jako problem poza głównym nurtem społeczeństwa, a jego rozwiązaniem miało być po prostu „przeciąganie” wykluczonych na „naszą” stronę z pominięciem troski o przyczyny zjawiska wykluczenia, a także z pominięciem zagadnień związanych z coraz to nowymi rodzajami nierówności społecznych, które generują wykluczenie w coraz to szerszych obszarach życia. Cała strategia traktowania w kategoriach Innego wpływa na tzw. „strategię symbolicznego wykluczenia", dzięki której łatwiej jest oskarżać wykluczonych o spowodowanie sytuacji, w jakiej się znaleźli. W tym celu wielu działaczy sceny politycznej wykorzystywało $\mathrm{w}$ sposób instrumentalny pojęcia underclass i kultura ubóstwa, zwracając uwagę głównie na te elementy charakterystyki grupy, które wskazywałyby, że jednostki same, poprzez swoje postawy, działania, zaniechania i zaniedbania, winne są sytuacji, w jakiej się znalazły. Ludzi z underclass opisywano jako wyalienowaną, zgettoizowaną, spatologizowaną, pełną przemocy grupę, która wegetuje na dnie społeczeństwa. Takie podejście miało wskazywać na odmienność ludzi dotkniętych biedą, aby w ten sposób pozbawić resztę społeczeństwa poczucia odpowiedzialności za ich los. Demonizowanie obu pojęć i traktowanie ich jak społecznych etykiet i stygmatów doprowadziło w wielu krajach, zwłaszcza w USA, do 
zmiany polityki wobec osób dotkniętych ubóstwem na surowszą i mniej efektywną. Retoryka tych, którzy starali się przekonać opinię publiczną o zagrożeniu, jakie rzekomo stanowią członkowie underclass, sprawiła, że społeczeństwo odwróciło się plecami do ludzi potrzebujących pomocy, obarczając ich winą i odpowiedzialnością za sytuację, w jakiej się znaleźli, a nawet obarczając ich odpowiedzialnością za inne niekorzystne zjawiska społeczne, takie jak przestępczość czy recesja. Pojęcia zaczęto z czasem używać w potocznej retoryce pogardy i dyskryminacji wobec ludzi zaliczanych do niższych klas społecznych (Bauman 2012, 169-178). Obecnie w oficjalnym, poprawnym politycznie dyskursie społecznym pojęcia underclass i kultura ubóstwa zostały zakwestionowane jako stygmatyzujące i pejoratywne. Jednakże, obserwując debaty polityczne w sprawie biedy, zwłaszcza amerykańską i brytyjską, nietrudno zauważyć, że są one nadal obecne w świadomości społecznej, choć niekoniecznie otwarcie werbalizowane. Debata nad kategorią underclass i kulturą ubóstwa przeniosła swój punkt ciężkości na płaszczyznę badań społecznych, gdzie, odchodząc od ewaluatywnego i normatywnego ciężaru tych pojęć na gruncie etyki społecznej i teorii sprawiedliwości, stosuje się je głównie w zakresie deskryptywnym, starając się dowieść ich skuteczności w badaniach nad ubóstwem.

W Wielkiej Brytanii prace badawcze nad zjawiskiem podklasy trwały od końca lat 80-tych. Do tradycyjnego rozróżnienia na trzy klasy: wyższą, średnią i niższą Charles Murray i Lydia Morris dodali czwartą kategorię, właśnie underclass. Murray w roku 1989 przeniósł pojęcie podklasy na grunt brytyjski, obserwując analogiczne zjawiska w społeczeństwie brytyjskim i amerykańskim. Jednakże badania Murraya i Morris przynosiły rozbieżne rezultaty, nie dając podstaw do formułowania jednoznacznych wniosków. Stąd np. John Westergaard i Lester I. Morris (Morris 1994; Westergaard 1992) podważają zasadność tezy o istnieniu underclass w Wielkiej Brytanii. Zdaniem Murraya nie można jednak podważyć tego, że mamy do czynienia z realną groźbą ukształtowania się społecznej podklasy, mimo że aktualnie obserwujemy dopiero wzrost liczebności i koncentrację osób o niepewnym statusie zawodowym i szansach życiowych.

Badania nad kategorią underclass prowadzono także we Francji, gdzie również zwrócono szczególną uwagę na fakt koncentracji ludzi ubogich, wykluczonych, głównie mniejszości etnicznych na obrzeżach miast (pisał o tym Oscar Lewis, por. 1963; 1974). Nadal jednak obszary te nie są uważane za klasyczne kultury getta i nazwano je underclass raczej z rozpędu i dla teoretycznego uproszczenia.

Christopher Whelan prowadził badania nad strukturą społeczeństwa w Irlandii pod kątem krystalizacji, agregacji i wyróżnienia underclass. Założył, że wyznacznikami underclass są: długotrwałe bezrobocie, przynależność kulturowa (głównie mniejszości) i rasowa, a także segregacja przestrzenna. Opierając się na wynikach swoich badań, wskazywał, że, po pierwsze, istnieje duża grupa ludzi, którzy po stracie pracy nie wyróżniają się marginalizacją przestrzenną, a co za tym idzie, tworzeniem gett ubogich. Po drugie, badacz nie znalazł dowodów na międzypokoleniowe dziedziczenie biedy. Podobna sytuacja miała miejsce w Holandii. Nie zidentyfikowano tam jednoznacznie 
istnienia tego typu klasy, zauważono jednak, że długotrwałe przebywanie na bezrobociu osób, które nie mają szansy powrotu na rynek pracy, stwarza groźbę powstania podklasy. Jak wynika z powyższych relacji, badania nad kategorią underclass w różnych krajach dawały odmienne rezultaty. W wielu nie potwierdzono obecności grupy charakteryzującej się całym zestawem cech przypisywanych podklasie, jednakże wskazywano na obecność specyficznej grupy osób trwale ubogich. Dyskusja nad istnieniem podklasy jako realnego tworu w wielu krajach nie dała jednoznacznych odpowiedzi.

Krytycy underclass podkreślają przede wszystkim nieoczywiste założenie o odrzucaniu przez członków podklasy dominującego w danym społeczeństwie systemu wartości, zwłaszcza w odniesieniu do wartości klasy średniej. Badania Williama Ryana, Leonarda Goodwina oraz Stephena Millera i in. (Goodwin 1972; William 1971; Miller 1971) dotyczące wyboru deklarowanego systemu wartości oraz stosunku do pracy wskazały, że nie istnieje zasadnicza różnica między hierarchią wartości deklarowaną przez członków underclass a innymi kategoriami społecznymi, nie zaobserwowano też negatywnego stosunku podklasy do pracy. Miałoby to dowodzić bezzasadności argumentów o znaczeniu moralnym. Zwolennicy teorii kulturowej, a ponadto badacze moralności w nurcie teorii poznawczo-rozwojowych wskazują jednak na fakt, że czym innym są deklaracje ludzi (tu: ubogich), czym innym zróżnicowana wśród nich umiejętność konsekwentnej realizacji przyjmowanych i deklarowanych wartości.

Bardziej umiarkowani zwolennicy underclass odrzucają argumenty i oskarżenia mówiące o złej woli, świadomej walce i manifestacji wrogości underclass wobec klasy średniej i jej moralności oraz stylu życia. Charakterystyczny dla underclass styl życia, strategie i wybory mają raczej podłoże adaptacyjne (racjonalne przystosowanie do specyficznych warunków) i nie są efektem świadomego wyboru alternatywnej moralności czy zgoła amoralności.

Kolejny zarzut kierowany pod adresem zwolenników kulturowo uzasadnianej underclass dotyczy tendencji do formułowania nieuprawnionych uogólnień (zwłaszcza pomijających lokalne różnice w obrębie struktury i kultury społeczeństw), uproszczonych interpretacji danych i arbitralności niektórych stwierdzeń i tez.

Zdaniem Domańskiego, jednego z krytyków ujęcia kulturowego, pozytywnie należy ocenić sam fakt identyfikacji i diagnozy syndromów zachowań zaliczanych do kultury ubóstwa, których istnienia nie można zignorować. „Zachowania te pozwalają umiejscowić ludzi ubogich w strukturze społecznej, ze względu na specyficzne atrybuty tej kategorii, jakimi są, przykładowo, niskie aspiracje edukacyjne, skrócone dzieciństwo, fakt dezorganizacji rodzin, niska samoocena, poczucie bezsilności, marginalizacja, fatalizm i świadomość wyłączenia ze świata <równych>" (Domański 2002, 106). Ulf Hannerz wskazał zaś na okoliczność, że krytyka podejścia kulturowego wynika głównie z tego, że nie dokonano w niej wyraźnego rozróżnienia (albo błędnie je zinterpretowano) między przyczynami a symptomami (przejawami), między zewnętrznymi przyczynami (głównie strukturalnymi) a wytworami, analizując i objaśniając kulturowe strategie radzenia sobiez 
obiektywnymi skutkami ubóstwa. Błędna interpretacja i niejasne rozróżnienia sprawiają, że pojęcie „kultury ubóstwa” nie jest stosowane jako „strategia radzenia sobie”, lecz jako „sposób na życie”, świadomie wybrany przez jednostki czy nawet całą społeczność. Dlatego Hannerz podkreśla znaczenie łączenia podejścia strukturalnego i kulturowego w badaniach nad kulturą ubóstwa, czego wyrazem jest tzw. podejście syntetyczne (Hannerz 1969).

Sami badacze posługujący się kategorią underclass, jak np. W. Wilson zdają sobie sprawę z niedostatków teorii podklasowej, a zwłaszcza z problemów definicyjnych (Jencks 1989) i metodologicznych, z niejasności terminologicznych wynikających ze złożoności badań, negatywnej „prasy” ze strony polityków i negatywnych emocji społecznych wobec ubogich i wykluczonych (niektórzy naukowcy pod presją opinii publicznej wycofali się z badań nad podklasq). Mimo iż określenie underclass jest niedoskonałe, to stanowi użyteczne narzędzie badań nad ubóstwem. Sugeruje ono bowiem, „że wystąpiły poważne zmiany w dzielnicach śródmiejskich gett oraz, że grupy, które tam pozostają są kolektywnie różne od tych, które zamieszkiwały te tereny wcześniej, a unikanie użycia tego terminu niefortunnie może utajnić znaczenie tych głębokich zmian jakie dokonały się w strukturze klasy i zachowaniach społecznych śródmiejskich gett” (Jencks 1989, 41). Wilson najbardziej zabiega o uznanie jakościowej odmienności underclass, co jest istotne w świetle walki z nowym rodzajem ubóstwa.

Brak spójności w wynikach badań nad istnieniem podklasy może być spowodowany m.in. brakiem zgodności terminologicznej nie tylko w obszarze pojęcie underclass, ale samej klasy. Dotychczas nie udało się wypracować jednoznacznego modelu, który pozwoliłby rzetelnie opracować klasowy obraz struktury społecznej. Nie ma jasnych granic między klasami, ich liczba w zależności od przyjętego paradygmatu jest zmienna, również kryteria określające przynależność klasową są zróżnicowane i płynne. Podstawę większości analiz nad stratyfikacją społeczną stanowią teorie klasy wypracowane jeszcze przez Karola Marksa (klasa w teorii konfliktu), Maxa Webera (ujęcie wielowymiarowe klasy) i Erika Olina Wrighta (klasy w teorii eksploracyjnej).

Dlaczego zagadnienie klasy społecznej jest istotne z punktu widzenia dyskusji nad zjawiskiem ubóstwa. Gdy przyjmiemy założenie, że specyficzna grupa ubogich tworzy coś na kształt klasy społecznej, wówczas możemy rozważać reproduktywność pewnych wzorów zachowań, postaw, wartości, kultury, zwłaszcza w obszarze języka, które obok czynników strukturalnych będą oddziaływały na rozwój jednostki i nabywane przez nią (bądź nie) kompetencje społeczne. Należy zatem sprawdzić, czy w oparciu o najbardziej wpływowe teorie i analizy zjawiska klasy społecznej, można uznać ubogich za grupę ludzi wyróżniającą się spośród reszty społeczeństwa charakterystycznym (zależności od przyjętych kryteriów) zestawem cech. 


\section{Charakterystyka underclass jako klasy społecznej}

Underclass można rozpatrywać jako klasę społeczną (dosłownie podklasę) w różny sposób, w zależności od przyjętej przez nas definicji klasy. Gdy przyjmiemy definicję klasy za Karolem Marksem, pojmującym ją jako grupę ludzi o podobnym stosunku do środków produkcji, wówczas ta kategoria osób (głównie z uwagi na długotrwałe pozostawanie poza rynkiem pracy i nieuczestniczenie w życiu publicznym) nie może być zakwalifikowana jako klasa społeczna. Przyczyna leży w niemożności usytuowania jej względem pozostałych klas, gdyż członkowie tej grupy są wyłączeni z posiadania, używania czy jakiegokolwiek innego udziału w środkach produkcji (Kołakowski 1988). Podobna sytuacja zachodzi, gdy zastosujemy neomarksowską koncepcję klasy według Wright (1997). Długotrwałe pozostawanie poza rynkiem pracy członków underclass sprawia, że nie podlegają oni kryteriom operacjonalizacji klasy w tym ujęciu (do tych kryteriów zalicza się zaś poziom wykształcenia, tytuł zawodowy i stopień autonomii wykonywanej pracy). Ze względu na pozostawanie biednych poza obrębem procesów produkcji, a co za tym idzie, brak kwalifikacji i potencjału ekonomicznego badacze tacy, jak m. in. Wright, czy Henryk Domański nie włączają osób trwale ubogich w strukturę klasową. Underclass jest kategorią, która nie mieści się w schemacie klasy niższej ani też nie przystaje do formuły marginesu ubóstwa.

Jednakże problem klasyfikacji osób pozostających poza systemem produkcji i wyłączonych z relacji do nich nie dotyczy jedynie ubogich i bezrobotnych. Obydwa modele klasy społecznej trudno jest odnieść do jednostek, które są ekonomicznie bierne takich jak emeryci, renciści, studenci, gospodynie domowe czy bezrobotni. Podejmuje się próby kwalifikacji tych kategorii osób do klas np. na podstawie uprzednio wykonywanego zawodu w przypadku emerytów i bezrobotnych, na podstawie kierunku studiów i prognozowanej profesji w przypadku studentów czy na podstawie zawodu wykonywanego przez męża dla ustalenia pozycji gospodyń domowych. Są to jednak starania niedające dobrych rezultatów, głównie ze względu na trudność z ujęciem wielowymiarowych czynników określających przynależność klasową w prognozowaniu (studenci) czy nawiązywaniu do poprzedniego zawodu (emeryci, bezrobotni) (Marshall 1996).

Gdy odwołamy się do klasy w ujęciu Webera, rozumianej jako grupa osób o podobnej pozycji rynkowej, ale też pokrewnym statusie społecznym (wyrażającym się głównie poprzez styl życia) oraz podobnych szansach życiowych (Weber 2002), wówczas określenie podklasa będzie się odnosić do najniższej pozycji, jaką zajmują osoby do niej zaliczane, jako że ich szanse życiowe są na relatywnie najniższym poziomie społecznym. W weberowskim modelu stratyfikacji społecznej dodatkowym czynnikiem wyróżniającym tę grupę spośród innych osób o niskich szansach życiowych, zdeprawowanych ekonomicznie, będzie styl życia i orientacje jednostek (implikowane przez „honor” czyli prestiż społeczny) oraz dziedziczenie i utrwalanie owego stylu przez kolejne pokolenia. Zatem ujęcie weberowskie wydaje się bardziej adekwatne od marksowskiego 
i neomarksowskiego o tyle, o ile pozwala dowieść odrębności i swoistości underclass.

Współczesne ujęcia stratyfikacji klasowej wykraczają poza ujęcia oparte na warunkach materialnych i zatrudnieniu, obejmując czynniki kulturowe takie, jak styl życia i wzorce konsumpcyjne. Pierre Bourdieu albo Mike Savage (Bourdieu 2005; Savage 2013) przekonują, że to właśnie prezentowany styl życia, posiadany przez jednostki kapitał kulturowy, symboliczny i ekonomiczny są wyróżnikami klas społecznych współczesnych społeczeństw. Bourdieu postrzega klasę społeczną jako zjawisko wykraczające daleko poza konotacje ekonomiczne czy zawodowe. O przynależności do klasy społecznej decydować ma nie tyle posiadanie czy brak środków produkcji albo konkretny zawód, lecz cały zestaw społecznych cech wpływających na miejsce jednostki w strukturze społecznej. Klasa charakteryzuje się tym, że w jej skład wchodzą jednostki o podobnych praktykach życiowych, podobnym spojrzeniu na świat - posługując się językiem Bourdieu - jednostki wyróżniające się analogicznym habitusem. Habitus opisuje Bourdieu w następujący sposób:

„Struktury konstytuowane dla pewnego szczególnego typu środowiska (...) wytwarzają habitus, system trwałych dyspozycji, struktury ustrukturowane predysponowane do działania jako struktury strukturujące, tzn. jako zasady generowania i strukturowania praktyk i wyobrażeń, które, nie będąc bynajmniej efektem poddania się reguło, mogą być obiektywnie ,regulowane' i ,regularne'; nie wiążąc się ze świadomym dążeniem do określonych celów i wyraźnym opanowaniem działań niezbędnych do ich osiągnięcia, są obiektywnie dostosowane do celów, którym służą; a przy tym wszystkim, nie będąc wynikiem organizującego działania dyrygenta, mogą być kolektywnie orkiestrowane" (Bourdieu 2007, 192-193).

Habitus jest więc wytworem warunków materialnych, społecznych i historycznych, jakim podlega jednostka $\mathrm{w}$ danej grupie (klasie). Warunki te wpływają na rezultat oddziaływań socjalizacyjnych, na interioryzowane przez całe życie normy i wartości oraz wytwarzane dyspozycje, oceny, modele działania jednostki, które są zgodne z utrwalonymi i charakterystycznymi dla danego środowiska schematami bądź wzorami zachowań (Bourdieu 2005). W tym ujęciu charakterystyczne cechy underclass, tak jej wymiar strukturalny jak i kulturowy, upoważniają do uznania jej za swoistą klasę, grupę o statusie najniższym w drabinie społecznej, która poprzez specyficzne warunki funkcjonowania (habitat - zasoby środowiskowe i infrastruktura społeczna) wytwarza habitus odmienny względem dominującego czy tradycyjnego.

Teoria strukturacji według Bourdieu, skupiająca się na różnicach w posiadanym kapitale kulturowym, społecznym i symbolicznym (nie zaś tylko ekonomicznym), wskazująca na sposób życia jako efekt zestroju warunków nań wpływających, a także na kryterium przynależności grupowej, pozwala wykazać kulturową swoistość underclass, a także rozpatrywać sposób życia jej członków jako odmienny w stosunku do sposobu funkcjonowania innych grup społecznych.

Nurt krytyczny wobec underclass nie zgadza się jednak z tezą, że ludzie ubodzy, dotknięci szeregiem niekorzystnych zmian społecznych w krajach kapitalistycznych, 
tworzą odrębną klasowo grupę. Krytycy powołują się przy tym na argument wewnętrznej spójności klasy społecznej, która ich zdaniem nie występuje w grupach uznawanych za podklasowe. Wskazują na tymczasową przynależność wielu ubogich do podklasy, co również narusza zasadę międzypokoleniowej i wewnątrzwspólnotowej przynależności klasowej. Nie negują jednak istnienia grupy ludzi wyodrębniającej się w strukturze społecznej wskutek długotrwałego pozostawania bez pracy wraz z towarzyszącą temu deprywacją materialną i uzależnieniem od pomocy społecznej. Nie są jednak skłonni uznać, że grupa ta wypracowała odrębne względem głównego nurtu podstawy kulturowej tożsamośc (Lee 1994; Gallie 1988, 1994).

Swoista odrębność trwale ubogich spowodowała, że kategoria podklasy była stale rozważana i wykorzystywana w wielu badaniach, głównie jako teoretycznie użyteczna definicja i podstawa do analizy złożonych procesów zachodzących w strukturze nowoczesnych społeczeństw kapitalistycznych oraz antropologicznych, socjologicznych i psychologicznych badań nad kulturowym i behawioralnym aspektem życia w ubóstwie. Wielu badaczy początkowo sceptycznych wobec pojęcia podklasy potwierdzało $\mathrm{w}$ wynikach swoich badań zasadność tych rozważań, nie tylko teoretyczną, ale też praktyczną. Za przykład posłużyć mogą tu dociekania Alana Buckinghama, który podjął rozważania nad zasadnością używania pojęcia podklasy w stosunku do społeczeństwa brytyjskiego. Wyniki jego badań wykazały różnorodność materialnej formy funkcjonowania underclass w różnych krajach; podklasa brytyjska nie odpowiadała dokładnie podklasie amerykańskiej, jednakże, zdaniem Buckinghama, nieizomorficzny charakter, tak w strukturze, jak i formach funkcjonowania grup ubogich w różnych krajach, nie powinien być pretekstem do odrzucenia owego użytecznego skądinąd pojęcia i uznania jego obecności w dyskursie fachowym za bezzasadną czy nieuprawnioną. Istotne dla Buckinghama było wykazanie, że wśród analizowanych grup obejmujących osoby trwale ubogie zaobserwować można charakterystyczne, odmienne względem klasy robotniczej, wzorce zakładania rodzin, zaangażowania w pracę, lojalności politycznej etc. Łącząc to z dowodami na międzypokoleniową ciągłość członkostwa oraz z powszechnym brakiem umiejętności zawodowych i obniżonym poziomem zdolności poznawczych, badacz wykazał, że zasadnie jest mówić o zestawie cech odróżniających tę grupę ubogich od innych grup lokowanych w dolnych warstwach struktury społecznej (Buckingham 1999).

Dyskusja nad faktycznym istnieniem podklasy, jej cechami i formami funkcjonowania, pozostaje nadal żywa wśród badaczy struktury społecznej. Zdaniem Duncana Gallie, w każdym społeczeństwie znajduje się odrębna grupa ludzi, która ponosi największy ciężar przemian ekonomicznych, cierpi z powodu długotrwałej marginalizacji na rynku pracy oraz doświadcza większej deprywacji niż niska klasa robotnicza. Grupa ta jest na tyle liczna, że można ją traktować jako odrębną klasę, choć sam autor powątpiewa w istnienie świadomości klasowej tej grupy (Gallie 1994).

Również w Polsce toczy się spór między krytykami underclass w polskim społeczeństwie a tymi, którzy dostrzegają pewne jej warianty chociażby w postaci 
środowisk popeegerowskich (Niedzielski \& Kisiel 2001; Domański 2002; Poławski 1977; Tarkowska 1999; Wódz 1994). Sporu dotychczas nie rozstrzygnięto, a obserwując jego przebieg, można rokować, że nie nastąpi to szybko. Nie wyklucza to jednak stosowania koncepcji underclass jako użytecznej i funkcjonalnej kategorii heurystycznej dla różnego rodzaju badań nad zjawiskiem długotrwałego ubóstwa. Pozwala ona bowiem odróżnić jednostki borykające się z problemem deprywacji materialnej okresowo, od tych, które funkcjonują w specyficznych warunkach wykluczenia, wyróżniających się charakterystycznym systemem zachowań, uwikłanych w długotrwałą, międzypokoleniową biedę. Wielu badaczy problemu ubóstwa, jak chociażby Domański, podkreśla, że bardzo trudno jest badać zjawisko ubóstwa z powodu braku przejrzystych kryteriów wyboru grupy badawczej. Trudno jest wytyczyć granice i ramy, w których dałoby się określić, czy ktoś jest czy nie jest biedny. Stąd też tak ważną sprawą jest wybór teorii, która poprzez swoistą operacjonalizację pojęcia wyodrębnia rzeczywistą grupę osób, podlegających badaniu.

By dopełnić klaryfikację pojęciową, a także jeszcze dokładniej scharakteryzować specyficzne środowisko życia, jakim są enklawy długotrwałej biedy, przyjrzymy się jeszcze pojęciu „kultury ubóstwa”, które wykorzystywane jest przez badaczy underclass, jednak faktycznie stanowi odrębną teorię i orientację badawczą.

\section{Koncepcja „kultury ubóstwa” Oscara Lewisa}

Oscar Lewis, amerykański antropolog, badał portorykańską społeczność Nowego Jorku i ubogą ludność Ameryki Łacińskiej pod kątem kulturowych podstaw długotrwałego ubóstwa. Rezultaty tych badań zaprezentował po raz pierwszy w 1958 r. w trakcie International Congress of Americanists w San José, wprowadzając nową koncepcję kultury ubóstwa (culture of poverty). Według jego koncepcji „kultura ubóstwa jest to pewien sposób życia szczególnie niezmienny i trwały, przechodzący z pokolenia na pokolenie w poszczególnych rodzinach. Kultura ubóstwa ma dla tych, którzy należą do jej kręgu, właściwe, przypisane sposoby postępowania i wyróżniające społeczne i psychologiczne skutki. Jest dynamicznym czynnikiem, który bierze udział w szerszej narodowej kulturze, a sam staje się jakąś subkulturą" (Lewis 1973, 25).

Lewis wyraźnie zaznacza w swoich pracach, że subkultura ubogich tworzy się jedynie w specyficznych warunkach i nie dotyczy wszystkich osób żyjących w ubóstwie (czyli ma charakter wybiórczy). Istotna dla tworzenia się tego zjawiska jest specyfika biedy doświadczanej przez ludzi. Bieda krótkoterminowa, incydentalna, czy tzw. ubożenie nie stanowią pożywki dla rozwoju cech właściwych subkulturze ubóstwa. Lewis wskazuje na przykład na członków klasy średniej, którzy, doświadczając epizodów ubóstwa, a nawet żyjąc przez pewien czas w slumsach, za sprawą nabytych wcześniej wartości, przyswojonych norm, wyrobionej umiejętności ich przestrzegania i utrwalonego stylu życia klasy średniej, nie tworzą kultury ubóstwa. Podobnie inne grupy, odznaczające się poczuciem przynależności grupowej (np. religijnej i kulturowej wśród Żydów) nie 
wykazują skłonności do generowania symptomatycznych dla kultury ubóstwa norm i postaw (Lewis 1963, 7-9).

Ustalając warunki, pod jakimi zachodzi tworzenie się tej formy kultury, Lewis wskazywał tak na czynniki strukturalne, jak na ideologiczne, psychologiczne oraz na podłoże kulturowe, z jakiego wywodzą się członkowie ubogiej społeczności. Czynniki strukturalne, na które wskazuje badacz, są podobne do tych, o których była mowa przy wstępnej charakterystyce podklasy: bezrobocie, izolacja społeczna, gettyzacja, niskie szanse na zdobycie zatrudnienia, niski poziom edukacji itd. Deprywacja finansowa w każdym środowisku degeneruje warunki życia i generuje podobne problemy, a tym samym, wymusza podobne systemy zachowań. Dlatego też jest to zdaniem Lewisa koncepcja o uniwersalnym zasięgu, jednak jedynie w odniesieniu do pewnego typu ubóstwa, występującego głównie w krajach rozwiniętych, nie zaś tego, z jaki możemy spotkać w krajach rozwijających się, związanego głównie z biedą na poziomie egzystencji biologicznej. Kultura ubóstwa tworzy się w społeczeństwach spełniających określone, sprzyjające temu zjawisku, warunki. Karwacki za Lewisem formułuje i wymienia wobec tego następujące warunki:

1. „przede wszystkim istnienie gospodarki towarowo-pieniężnej oraz pracy zarobkowej i produkcji dla zysku;

2. stale wysoki procent bezrobotnych i dorywczość zatrudnienia robotników niewykwalifikowanych;

3. niskie zarobki;

4. brak możliwości tworzenia organizacji socjalnych, politycznych i gospodarczych wśród najbiedniejszych w wyniku niemocy ludzi pod naciskiem rządowym (...);

5. istnienie w klasie panującej szeregu wartości, które kładą nacisk na pomnażanie majątku, awans społeczny i dopatrują się w kiepskiej sytuacji materialnej osobistej nieudolności i niższości” (Karwacki 2006, 99).

Na liście Karwackiego kontrowersje budzi warunek czwarty mówiący o niemożliwości tworzenia organizacji w środowiskach osób ubogich. Lewis zwracał uwagę na to, że brak udziału osób ubogich w organizacjach społecznych czy wszelkich przejawach życia publicznego jest jednym z wyróżników subkultury nędzy, jednak był on wynikiem głównie postaw i przekonań dominujących wśród jej członków, czyli czynników psychologicznych, a nie strukturalnych czy formalnych. Są to jednak ważne czynniki, istotne dla wytworzenia się kultury ubóstwa. Do listy Karwackiego należałoby też dodać strukturę zatrudnienia i wysokość zarobków oraz wykształcenie dorosłych przedstawicieli grupy. Podobnie zatem jak w ujęciu syntetycznym teorii underclass $\mathrm{u}$ Wilsona, kultura ubóstwa wytwarza się poprzez połączenie strukturalnej podstawy społecznej oraz wytwarzanych i co najważniejsze, przekazywanych pokoleniowo czynników kulturowych wpływających na postawy, styl życia i działania jej członków. „Kultura ubóstwa jest kategorią (...) determinującą sposób zachowań, hierarchie wartości 
ludzi ubogich (...) określającą sposób socjalizacji kolejnych pokoleń. Kultura ubóstwa, gdy już istnieje, ma duży wpływ na dzieci" (Kraczla 1993, 9). Ma więc swój początek niejako w strukturalnych warunkach, jednak to czynnikom psychologicznym i ideologicznym, które predysponują do rozwoju kultury ubóstwa, Lewis poświęcił szczególną uwagę w swojej koncepcji. Wyodrębnił on cztery poziomy analizy dla kultury ubóstwa, wyróżniając na każdym z nich charakterystyczne dla tego stanu cechy:

Po pierwsze, poziom szerszego społeczeństwa: kultura nędzy odznacza się brakiem czynnego uczestnictwa $\mathrm{w}$ dużych instytucjach (np. brak przynależności do partii politycznych, stowarzyszeń). Wynika to m.in. z braku środków finansowych, czasami dyskryminacji, lęku, podejrzliwości bądź apatii. Brak związków z instytucjami szerszego społeczeństwa przekłada się na brak uczestnictwa w życiu społeczności. Samo uczestnictwo $\mathrm{w}$ jakiejś organizacji nie jest równoznaczne z tym, że dana osoba nie przynależy do „kultury biedy”. Dodatkowo na tym poziomie „kultura biedy” cechuje się trwałym bezrobociem, dorywczością pracy, częstym zastawianiem rzeczy osobistych, pożyczaniem pieniędzy, nabywaniem głównie ubrań i rzeczy używanych. Charakterystyczna jest też krytyka zasadniczych instytucji społecznych, wyrażana np. niechęcią do policji, dygnitarzy i rządu.

Po drugie, poziom lokalnej społeczności - główne problemy to zmaganie się z kiepskimi warunkami mieszkaniowymi, ciasnotą, powszechna niechęć do obcych, zamykanie się w kręgu rodziny, niechęć do sąsiadów i otoczenia.

Po trzecie, poziom rodziny - na tym poziomie główne cechy charakteryzujące kulturę ubóstwa to brak dzieciństwa jako specjalnego etapu w życiu objętego szczególną ochroną, powszechny konkubinat ${ }^{8}$, tendencja do tworzenia rodzin matriarchalnych.

Po czwarte, poziom psychologiczny (indywidualnej jednostki) - główne cechy takich osób to poczucie bycia wykluczonym i zepchniętym na margines społeczeństwa, bezradność, skłonność do uzależnień, niska samoocena. „Rezygnacja, fatalizm i duża pobłażliwość w stosunku do licznych patologii to codzienność trwale ubogich" (Lewis 1973).

Kultura ubóstwa jest więc adaptacyjną (systemem przystosowania do szczególnych warunków życia) subkulturą i stylem życia charakterystycznym dla ludzi żyjących w długotrwałej, wielopokoleniowej biedzie, najczęściej zamieszkujących na przedmieściach wielkich miast (slumsy) lub zacofanych regionach wiejskich (np. byłe PGRy). Jest to zjawisko o pewnym stopniu uniwersalności, o odrębności którego decydują specyficzne stosunki społeczne, wzory zachowań, sposób życia, normy i wartości przekazywane z pokolenia na pokolenie w procesie socjalizacji. Jednostki wychowane w kulturze ubóstwa wyróżniają się pewnym zestawem cech, wśród których można wymienić wrogi stosunek

8 Ta cecha staje się coraz mniej charakterystyczna dla tych środowisk, co wiąże się ze zmianami społecznymi i podejściem do instytucji małżeństwa, jednakże nadal w tych kręgach konkubinat jest powszechny. Często wynika to z kalkulacji ekonomicznej rodziców, gdyż samotna matka/ ojciec jest w stanie uzyskać wyższe świadczenia z opieki społecznej, niż osoba będąca w związku małżeńskim. 
do otaczającego świata, wycofanie, orientację na teraźniejszość, niski poziom aspiracji (przekładający się bezpośrednio np. na brak zaangażowania w pracę jako główne źródło utrzymania), poczucie rezygnacji i niższości, brak poczucia sprawstwa i wiary w siebie, gotowość do tolerowania zachowań, które klasa średnia uznaje za dewiacyjne oraz fatalizm.

\section{Moralność a ubóstwo}

Aby doprecyzować kontekst zjawiska ubóstwa, zaanonsowany w tytule chciałabym teraz skupić uwagę na dwóch obszarach funkcjonowania osób trwale ubogich, a mianowicie sferze moralności oraz szeroko rozumianej partycypacji. Interesują mnie tutaj w szczególności procesy przekazu, nabywania i internalizacji norm, wartości, postaw, wzorów funkcjonowania moralnego i społecznego, które również mają wpływ na wykształcenie i jakość indywidualnych kompetencji moralnych i społecznych.

Analizując pracę czołowych propagatorów koncepcji kultury ubóstwa (Lewis, Glazer, Moynihan, Moynihan, Ball, Miller), wyróżnić można zestaw pewnych podstawowych założeń dotyczących sfery aksjologicznej członków tej subkultury. Przytoczmy je za L. Richardem Della Fave:

- istnienie zbioru wartości charakterystycznego dla ubogich;

- wartości te są wynikiem bezpośredniego doświadczenia życia w ubóstwie;

- codzienne działania ubogich znajdują się pod silnym wpływem tych wartości;

- wiele z tych działań postrzeganych jest przez resztę społeczeństwa jako dewiacyjne, zwłaszcza z punktu widzenia klasy średniej;

- wiele z tych zachowań jest dysfunkcjonalna dla ubogich, gdyż działania przez nich podejmowane utrudniają, bądź też uniemożliwiają im podniesienie się i wyjście z ubóstwa;

- w dużej mierze wartości te przekazywane są z pokolenia na pokolenie;

- ze względu na samonapędzający się charaktery tych wartości, ubodzy nie są w stanie wykorzystywać szans i możliwości na awans społeczny, nawet w sytuacji, gdy możliwości te się rozszerzają, głównie za sprawą działań instytucji społecznych (Della Fave 1974, 609-610).

Ryzykownym jest jednak wysuwać na podstawie powyższych założeń tezę o uniwersalnym systemie aksjologicznym w kulturze ubóstwa. Krytycy powołują się na wyniki wielu badań (William 1971; Rainwater 1970; Schneiderman 1964; Johnson 1971), które wykazywały, że wyznawane przez członków kultury ubóstwa wartości nie różnią się zbytnio od tych, jakie wyznają osoby z innych warstw społecznych. Twierdzą nawet, że ubodzy świadomie wybierają wartości przypisywane klasie średniej. Uważają je mianowicie za cenne, głównie z powodu preferowania ich przez ogół społeczeństwa. Zdaniem oponentów Lewisa dane te zaprzeczają jego teorii. Co prawda, krytycy są skłonni przyznać, że występuje szereg obszarów, w których zachowanie biednych 
różni się zdecydowanie od zachowania członków klasy średniej, jednak różnice te nie są spowodowane odmiennością pod względem preferowanych wartości, ale raczej są wynikiem wysiłków podejmowanych przez biednych dla opracowania wzorców zachowań, które umożliwiają im sprostanie wymogom sytuacji ubóstwa.

Współczesny nurt badań nad wartościami deklarowanymi przez różne grupy społeczne pozwala obronić tezę o charakterystycznym dla kultury ubóstwa systemie aksjologicznym. Badania te rzeczywiście nie wskazują na istotne zróżnicowanie pod względem wartości deklarowanych w badaniach. Wartości deklarowane przez członków klasy niższej są zbliżone do zestawu wartości szczególnie cenionych przez klasę robotniczą, a nawet do wartości klasy średniej. Jedną z przyczyn takiego stanu jest propagowanie wartości klasy średniej jako dominującego, preferowanego przez ogół społeczeństwa i propagowanego przez instytucje (np. przez szkołę) systemu aksjologicznego. Członkowie klas niższych zdają sobie sprawę ze społecznej przewagi pewnych wartości nad innymi, dlatego też często deklarują je jako swoje. Uzyskujemy wówczas sytuację, w której osoby przejawiające dewiacyjne zachowania, np. przestępcze, $\mathrm{w}$ trakcie badań deklarują sprawiedliwość jako ważną dla siebie wartość. Problemem tym zajmuje się m.in. niemiecki badacz Kay Hemmerling $(2009,2013)$. Prowadził on wieloletnie badania nad systemem wartości osób osadzonych w więzieniach. Wykazał w nich, że deklarowane przez więźniów wartości nie są odmienne od tych, jakie zgłaszają ludzie, którzy nie popełnili przestępstw. Do podobnych wniosków doszli także inni badacze, np. Donald R. Taft (1950, 181-182), Gresham M. Sykes i David Matza (1957, 664-670). Problem nie leży zatem po stronie tego, jakie wartości deklarują badane osoby, ale odnosi się do ich kompetencji w realizowaniu i pojmowaniu danych wartości. Tu właśnie pojawia się trudność, jeżeli chodzi o osoby wychowujące się w kulturze trwałego ubóstwa. Na poziomie deklaracji wartości, grupa ta nie wyróżnia się zbytnio, jednak ich świadomość i realizacja wartości są „obciążone” specyfiką środowiska życia, co skutkuje odmiennym stylem życia, wzorami zachowań, stosunkami społecznymi, poglądami oraz normami.

\section{Teoria wartości rozszerzonych według Hymana Rodmana}

Interesującą próbę wyjaśnienia tego zjawiska podjął Hyman Rodman w swojej teorii wartości rozszerzonych (value stretch) (Rodman 1963). Próbował on pogodzić dwie kontrastowe teorie dotyczące charakteru wyznawanych w społeczeństwach wartości, z których jedna reprezentowana np. przez T. Parsonsa (1969) i R. K. Mertona (2002) głosiła, że ogólny system wartości jest wspólny dla całego społeczeństwa, druga zaś, której zwolennikami byli np. Herbert H. Hyman i Allison Davis (por. Hymati 1953; Davis 1946), zakłada, że każda klasa społeczna posiada odrębny system wartości, zatem wartości są zróżnicowane ze względu na stratyfikacje społeczną i uzależnione od warunków życia. Rodman założył, że w rzeczywistości obie teorie da się pogodzić, gdyż każda z nich ma swoje odbicie w rzeczywistości. Podstawowe wartości są jego zdaniem podzielane przez 
członków wszystkich klas, także przez członków klasy niższej. Jednocześnie, jako wynik reakcji na swoiste, ograniczające możliwości warunki funkcjonowania osób ubogich, wyróżnia się w tej grupie specyficzne wartości, charakterystyczne tylko dla niej. Rodman założył zatem, że obie teorie są względem siebie komplementarne.

Główna teza koncepcji value stretch brzmi: osoby z klasy niższej bez rezygnacji z ogólnych wartości (głównie reprezentowanych przez wartości klasy średniej) rozwijają własny, alternatywny ich zestaw, który zawiera szereg wartości niższych, łatwiejszych do realizacji. Efektem tego jest posiadanie przez członków klasy niższej szerszego zestawu wartości niż posiada pozostała część społeczeństwa (Rodman 1963, 209). Koncepcja Rodmana opiera się na następujących założeniach:

- Ogólne wartości społeczne są podzielane przez wszystkich członków społeczeństwa, wszystkie klasy społeczne.

- Członkowie klasy niższej posiadają wartości prezentujące niższy poziom osiągnięć niż ogólne wartości społeczne.

- Członkowie klasy niższej mają szerszy zakres wartości niż członkowie wyższych klas.

- Członkowie klasy niższej poprzez ograniczenia, jakie stwarzają warunki, w których żyją, często nie są zdolni realizować wartości z poziomu klasy średniej.

- Członkowie klasy niższej mają świadomość, że ograniczenia te dotyczą również innych osób z ich środowiska.

- Ludzie mają tendencję do faworyzowania tych rzeczy i celów, które są dla nich możliwe do osiągnięcia. Równają w dół, obniżają swoje cele, gdy przynosi to rezultat w postaci poczucia osiągnięcia sukcesu, realizacji celów, poczucia spełnienia, bądź redukcji dyskomfortu psychicznego ${ }^{9}$.

- Członkowie klasy niższej z czasem zaczynają szczególnie pozytywnie oceniać te osiągnięcia, które są dla nich dostępne, nawet jeżeli są one lokowane (przez resztę społeczeństwa) nisko w ogólnej hierarchii wartości.

- Ze względu na powyższy mechanizm, członkowie klasy niższej mają tendencję do rozszerzania zakresu wyznawanych wartości (Della Fave 1974, 612-613).

W związku z powyższymi założeniami Rodman przyjął, że w klasie niższej koegzystują wartości szerokiego społeczeństwa (głównie wartości klasy średniej) oraz wartości charakterystyczne dla klasy niższej. Ważny jest tutaj nie tylko sam dodatkowy ich zestaw, ale również ich hierarchia, to jak układają się względem siebie i jak na siebie wpływają. Stąd też nazwa teorii, tj. „poszerzenie wartości” ${ }^{10}$, jako że zestaw wartości w

9 Sam Rodman zauważa jednak, że nie dotyczy to wszystkich osób z kultury biedy. Złożoność ludzkich zachowań i reakcji jest tak wielka, że nie można w tym przypadku traktować takiego zachowania jako uniwersalnego dla wszystkich członków underclass, jednak Rodman twierdzi, że jest to jedna z najczęstszych reakcji adaptacyjnych członków podklasy na brak zdolności do realizacji ogólnych wartości społecznych.

10 Wartości rozumiane są tu jako system, a nie pojedyncza wartość. Rozszerzeniu ulega więc zbiór wartości, choć pod dyskusję poddać można również hipotezę, o rozszerzaniu znaczenia poszczególnych wartości, szczególnie w przypadku wartości abstrakcyjnych, jednakże takie 
klasie niższej będzie szerszy niż pozostałych klasach, właśnie ze względu na dodatkowy, specyficzny dla tej klasy segment wartości, których nie podzielają pozostałe klasy.

Rodman opisał również proces, w wyniku którego dochodzi do poszerzania zestawu wartości w klasie niższej. Zrekonstruował go w oparciu o analizę wyników badań i obserwacji członków klas niższych z różnych krajów. Zauważył, że osoby z klasy niższej wchodzą ze sobą w częstsze relacje niż z przedstawicielami innych klas ${ }^{11}$. Mają podobne problemy, funkcjonują w tych samych warunkach, które w sposób istotny ograniczają ich możliwości, przez co bardzo trudno jest im osiągnąć kulturalne cele reszty społeczeństwa przy pomocy uznanych i dopuszczalnych środków. Potrzeba realizacji owych kulturalnych celów jest silna, ponieważ w oparciu o nie społeczeństwo dokonuje oceny jednostek, nagradza bądź karze za sposób ich realizacji. Potrzeba ta jest tak silna, że członkowie klasy niższej pozbawieni dostępu do „legalnych” środków służących do realizacji celów, sięgają po inne, alternatywne, które najczęściej są negatywnie oceniane przez społeczeństwo. Inną reakcją na niemożność zrealizowania kulturowych celów ogółu społeczeństwa jest negacja tych celów. Gdy członkowie klasy niższej spotykają się z negacją, karą ze strony reszty społeczeństwa, wywołuje to niechęć ubogich do tej części społeczności, rodzi frustracje, poczucie niższości, dyskomfort psychiczny. Sytuacje takie sprawiają, że tradycyjne wartości stają się źródłem ich negatywnych odczuć i mimo że z nich nie rezygnują, to coraz częściej zaczynają tolerować, ostatecznie zaś - aprobować, a nawet pozytywnie oceniać odchylenia od takiego sposobu wartościowania. Tak właśnie, w wyniku działań adaptacyjnych zaczynają wytwarzać takie wartości, które są łatwiejsze do osiągnięcia, nie powodują frustracji i poczucia niezdolności do osiągania celów. Dochodzą zatem cele, których realizacja wymaga zasobów i kompetencji, jakie są w posiadaniu członków underclass, dlatego też stają się one coraz bardziej popularne, akceptowane przez coraz większą liczbę osób z tego środowiska. Z czasem stają się charakterystyczne dla danej grupy ubogich (Rodman 1963).

Rodman w swojej teorii przyjmuje również dodatkowe założenie, że członkowie tych grup wzmacniają swoją pozytywną ocenę niższych wartości poprzez wchodzenie w interakcje z innymi, którzy są w podobnej sytuacji, przez co są postrzegani jako pozytywna grupa odniesienia. Zatem, w przypadku członków klasy niższej, mamy do czynienia z tzw. równaniem w dół, co pokazują również badania prowadzone w polskich środowiskach popegeerowskich (Niedzielski 2001; Karwacki 2006; Tarkowska 2000; Korzeniowska 2002). Niejednokrotnie badani przyznają, że z punktu widzenia integracji społecznej lepiej jestnie posiadać zbyt wiele, a ci, którzy osiągająjakiś sukces, bądźteż czasowo doświadczają poprawy warunków życia, są wykluczani lub poddawani innym negatywnym sankcjom przez resztę grupy. Sprawia to, że nie opłaca się mieć „trochę więcej” ${ }^{12}$ niż inni, ponieważ

podejście do problemu nie występuje w torii Rodmana.

11 Jest to efekt izolacji i autoizolacji.

12 Mowa tu o nieznacznej poprawie warunków materialnych, które nie są w stanie trwale ani znacząco zmienić sytuacji jednostki, nie pozwalając jej wyrwać się z kręgu ubóstwa. 
faktycznie nie poprawia to warunków funkcjonowania, ale paradoksalnie je pogarsza.

Rodman poparł swoją teorię poszerzonych wartości o wyniki licznych badań empirycznych, między innymi Raymonda T. Smitha i Lloyda Braithwaite'a, w których to sami badacze zauważali zjawisko poszerzania zbioru wartości, bądź jak to nazywali współwystępowania dwóch systemów moralnych - Smith (1956, 149), czy „dualizm przywiązania do wartości" (Braithwaite 1957, 534). Pojawienie się nowych, specyficznych dla środowiska ubogich, wartości nie powodowało $\mathrm{w}$ badanych społecznościach zanikania wartości ogólnych. Zatem nowe wartości, jako wynik adaptacji do warunków, są dodatkowym elementem, który wyróżnia środowisko osób ubogich. Przeto, gdy przyjmiemy założenia i argumentacje Rodmana, wówczas wyniki badań wskazujących na deklarowanie przez ubogich zbliżonego do reszty społeczeństwa systemu wartości, które mają być dowodem na niesłuszność teorii kultury ubóstwa stworzonej przez Lewisa, nie dają się utrzymać.

\section{Społeczność zamknięta i nieuczestnicząca}

Zdaniem Braithwaite’aludzie w kulturze ubóstwa mają silne poczucie marginalizacji, bezradności, zależności oraz braku przywiązania. Poczucie odrębności jest u nich tak silne, że nie ufają instytucją publicznym i nie postrzegają ich, jako służące ich interesom i potrzebom. Przkonanie to wzmaga wzrost poczucia bezsilności oraz niższości i osobistej niegodności (Braithwaite). Wśród członków kultury ubóstwa mała jest świadomość i poczucie przynależności historycznej. Są to ludzie na tyle zmarginalizowani, także w sferze tożsamości, że nie odczuwają więzi z żadną grupą kulturową, ideologiczną czy historyczną. Skupieni są na własnych problemach i to głównie problemach dnia codziennego, na swoim wąskim przestrzennie środowisku (głównie najbliższym sąsiedztwie), na własnym sposobie życia. Brak identyfikacji z innymi może być tak silny, że w większości przypadków osoby z kręgu kultury biedy nie będą się utożsamiać nawet z osobami znajdującymi się w podobnym położeniu. Jest to więc czynnik charakterystyczny i zarazem niezbędny dla powstania kultury ubóstwa. Lewis zaznacza nawet, że w sytuacji, w której osoba uboga staje się członkiem organizacji np. związków zawodowych, albo gdy przyjmuje internacjonalistyczną perspektywę na świat wówczas przestaje być częścią kultury ubóstwa, mimo iż finansowo nadal określa się ją jako ubogą(Lewis 1969).

Badacz podkreślił też szczególnie dziedziczność tych cech, czyli sposób życia przechodzący w poszczególnych rodzinach z pokolenia na pokolenie. „Kultura ubóstwa jest nie tylko dostosowaniem się do zestawu obiektywnych warunków szerszego społeczeństwa. Gdy zaistnieje ma tendencję do utrzymywania się z pokolenia na pokolenie, poprzez jej wpływ na dzieci. W okresie, kiedy dzieci slumsów są w wieku sześciu lub siedmiu lat, zazwyczaj absorbują podstawowe wartości oraz postawy z ich subkultury i nie są psychicznie nastawione na pełne wykorzystanie zmieniających się warunków i wzrastających możliwości, które mogą wystąpić w czasie ich życia” (Lewis 
1968, 188). Kultura ubóstwa jest wobec tego przyswajana w procesie socjalizacji, kiedy to jednostki uczą się pewnych wzorców myślowych, wzorów interakcji społecznych i strategii poznawczych, przyswajają specyficzne normy i wartości, które stają się trwałym elementem ich osobowości, determinują ich tożsamość i zachowania niezależenie od zmieniających się warunków otoczenia. Nie znaczy to, że członkowie subkultury ubóstwa nie ewoluują czy nie podlegają zmianom. Zwraca się jednak uwagę na fakt, że elementy kultury ubóstwa są na tyle trwałe i na tyle charakterystyczne, że odpowiadają w sposób dominujący za sytuację życiową osób z jej kręgu i nawet częściowa zmiana statusu materialnego nie gwarantuje, że członek tej kultury przestanie nim być. Dodatkowo instytucje społeczne, takie jak szkoły czy przedsiębiorstwa i firmy, działają w oparciu o system norm wytworzony przez klasę średnią, co stanowi dodatkowe utrudnienie dla osób, które w kulturze klasy średniej nie wyrastają. Widoczne jest to szczególnie w przypadku instytucji edukacyjnych, gdzie etos i kultura klasy średniej są dominujące tak w praktyce działań, jak i w treściach programu nauczania. Normy klasy średniej obowiązują w sposób nieoficjalny, ale nie uczy się ich tych, którzy są spoza kręgu tej klasy, co sprawia, że uczniowie ubodzy mają problemy adaptacyjne, wychowawcze i edukacyjne, wynikające $\mathrm{z}$ braku stosownych kompetencji społecznych i moralnych ${ }^{13}$. Widać to szczególnie wyraźnie w przypadku etosu pracy, który w kręgach biedy mocno odbiega od etosu cenionego przez członków klasy średniej. Wykazano, że „podstawowe cechy, którymi mogą się charakteryzować osoby pracujące, które doceniają jak pracowitość, uczciwość, utrzymanie dobrego stanu zdrowia, sprawność, na zasadzie przekazu mogą poprawić życiowe szanse dzieci, niezależnie od dochodów ich rodziców. Dzieci pochodzące z takich rodzin radzą sobie w życiu bez względu na wysokość dochodów ich rodziców, ponieważ dziedziczą pewne wzory" (Mayer 1997, 2-3). Badania w tym temacie prowadziła Susan Mayer, dla której ten międzypokoleniowy przekaz odgrywa znaczącą rolę w kształtowaniu się wzorców zachowań, wartości i norm socjalizowanych przez dzieci. Przekaz ten jest o wiele ważniejszy niż ekonomiczna sytuacja rodziców, co sprawia, że niekoniecznie biedne położenie rodziców musi determinować ubóstwo u ich dzieci, ważniejsze jest to, co rodzice są w stanie przekazać swoim dzieciom w procesie wychowawczym. Analizy losów jednostek lub pewnych grup kulturowych pokazały, że czynniki kulturowe dominują w tym zakresie nad materialnymi (Mayer 1997).

\section{Konsekwencje kulturowego ujęcia ubóstwa}

Opierając się na swojej tezie, Lewis opracowywał projekty pomocy osobom ubogim, które zakładały głównie pracę nad wzrostem kompetencji społecznych, edukacją i psychiką osób z kręgu kultury ubóstwa, a nie skupianie się wyłącznie na poprawie warunków zewnętrznych, zwłaszcza ekonomicznych. Z podejściem tym zgadza się wielu

13 Problemowi temu poświęcona jest książka Piotra Kostyłło (2008), a także badania Zbigniewa Kwiecińskiego. 
praktyków, pracowników socjalnych czy terapeutów pracujących z ubogimi, jak np. Linda J. Pearson, która w swojej pracy Understending the Culture of Poverty wyraża taką oto opinię: „Ubóstwo rzadko związane jest z brakiem inteligencji czy zdolności. Jednakże wiele osób tkwi w pokoleniowej biedzie, ponieważ nie są świadome strategii behawioralnych, które otworzyłyby im drzwi do innych możliwości i/lub nie mają nikogo, kto mógłby im pomóc nauczyć się reguł pochodzących z klasy średniej, aby mogli korzystać z zasobów" (Pearson 2003, 6). Praca socjalna w myśl tego podejścia miałaby polegać głównie na owym nauczaniu, a nie przekazywaniu środków finansowych czy materialnych, jak ma to głównie miejsce w większości systemów wsparcia społecznego.

Lewis nigdy nie wypracował jednolitej i spójnej teorii kultury ubóstwa. Krytycy Lewisa zarzucali mu, że zbytnio skupił się na czynnikach kulturowych i psychologicznych, które obciążone były trudnościami w pozyskiwaniu danych. Szczególnie ostrą krytykę rzetelności empirycznych dowodów teorii Lewisa przedstawił Charles Valentine w pracy z 1968 r. pt. Culture and Poverty: Critique and Counter-Proposals. Podobnie jak przytoczeni powyżej krytycy teorii, Valentine zawracał uwagę na fakt, że przy opisie kultury ubóstwa brak jest wyraźnego rozróżnienia między zachowaniami reprezentatywnymi dla ubogich a ich wartościami ${ }^{14}$. Zarzuty Valentine'a, choć w obliczu dzisiejszej wiedzy nie tak trafne jak to się początkowo wydawało, silnie wpłynęły na postrzeganie i interpretację koncepcji Lewisa, zwłaszcza w zakresie rzekomego „obwiniania ofiar biedy za ich ubóstwo” i oceny ubogich jako dewiacyjnej subkultury. Valentine w wyniku tych interpretacji zaliczył pracę Lewisa do tzw. „pejoratywnej tradycji” badań nad ubóstwem, reprezentowanej między innymi przez pracę The Negro Family in the United States Fraziera (1966) i The Negro Family: The Case for National Action Moynihana (1965).

Pomimo, iż Lewis nigdy nie powiedział, że biedni sami są winni swego ubóstwa, wręcz przeciwnie, zadawał pytanie o potrzeby akceptacji odmienności kulturowej względem tej specyficznej subkultury, to niezależnie od jego podejścia wokół pojęcia „kultury biedy” pojawiła się taka właśnie interpretacja. Lewis podkreślał, że badacze problemu, tak samo jak członkowie klasy średniej, których styl życia i moralność są w większości społeczeństw mainstreamowe, wyjątkowo krytycznie podchodzą do postaw życiowych, wartości czy norm wytwarzanych i preferowanych w ramach kultury ubóstwa. Sposób funkcjonowania jej członków oceniany jest w kategoriach aberracji, z przypisaniem winy i intencjonalności działań prowadzących do trudnej, niegodnej sytuacji życiowej. Ocena ta, zdaniem Lewisa, nie jest w pełni uprawniona. Nie było jego intencją chwalenie postaw osób ubogich, jednak w swoich pracach wskazywał na te elementy, które można oceniać w pewnych kontekstach pozytywnie, chcąc odmitologizować długotrwałą biedę postrzeganą jako jedynie źródło patologii, przestępczości i lenistwa. Wskazywał na przykład na element spontaniczności, wynikający głównie z braku myślenia o przyszłości i życia dniem codziennym u osób z kultury ubóstwa, którego brak w dominującej klasie

14 Valentine używał pojęcia „wartość” w znaczeniu możliwie szerokim, dotykającym także norm, celów i aspiracji ludzkich. 
średniej. Zaznaczał, że zbyt często negatywna ocena osób ubogich wynika ze skupiania się na przestępczych, patologicznych zachowaniach części z nich, które przypisywane są całości społeczności. Zbyt rzadko, jak pisał Lewis, mówi się zaś o ich trudach i cierpieniu (Lewis 1963), nie analizuje się przyczyn pewnych zjawisk, nie próbuje się znaleźć wyjaśnienia, a do oceny zachowań przykłada się miarę z zupełnie odmiennych (ze względu na warunki funkcjonowania) środowisk życia. Elżbieta Tarkowska w trakcie swoich badań nad problemem trwałego ubóstwa zauważyła, że

„sposób rozumienia kultury w badaniach biedy, w kontynuacjach i nawiązaniach do koncepcji Oscara Lewisa nie ma wiele wspólnego z jego oryginalną szeroką antropologiczną koncepcją, obejmującą różne wymiary życia jednostek i rodzin, które tworzą ich specyficzny sposób życia (way of life). Kultura w badaniach biedy często bywa sprowadzana do jednostkowych postaw i poglądów, które można dowolnie zmieniać i przekształcać (...) Kultura ujmowana szeroko, antropologicznie, jako składnik zewnętrznej wobec jednostki sytuacji, a nie jako wąska sfera wyboru i odpowiedzialności jednostek - nie mieści się w tym ujęciu" (Tarkowska 2000, 24).

Chaos terminologiczny związany $\mathrm{z}$ pojęciem kultury generuje również inne problemy, jak chociażby różnice w jakości i celu badań nad kulturą ubóstwa. Można mówić o dwóch dominujących podejściach, które doskonale ilustruje przekonanie charakterystyczne dla tej kultury, że mianowicie przyszłość nie może być w żaden sposób kontrolowana, które jedni badacze traktują jako jedną z przyczyn kultury ubóstwa, inni zaś jako jej cechę (Roach \& Gursslin 1965). Mamy więc dwa warianty rozumienia kultury: kultura jako opis, gdzie czołową rolę odgrywa opis wspólnego dla członków grupy sposób życia, bądź kultura jako przyczyna, gdzie wspólny dla grupy wzór funkcjonowania przekazywany międzypokoleniowo jest postrzegany jako czynnik tworzący zjawisko. Większość badaczy posługujących się pojęciem kultura ubóstwa używa go właśnie w tym drugim znaczeniu. Kultura ubóstwa jako przyczyna, by można było uznać ją za wiarygodną, wymaga zaistnienia dwóch warunków: po pierwsze, należy udowodnić, że kultura ta jest transmitowana międzypokoleniowo, po drugie, biedni w tej kulturze muszą mieć odmienny od reszty społeczeństwa system normatywny. Jednak jak dowodzą Jack L. Roach i Orville R. Gursslin w pracy pt. An Evaluation of the Concept „Culture of Poverty”, niełatwo jest to wykazać. Ich zdaniem elementy, na które najczęściej wskazują badacze kultury ubóstwa jako na charakterystyczne dla tej subkultury, jak cechy związane ze statusem materialnym, bliskością przestrzenną czy własnościami społeczno-psychologicznymi jednostki, nie są wystarczające do faktycznego stworzenia i utrzymania oryginalnej kultury. Zdaniem autorów krytyczne znaczenie dla istnienia subkultury ma charakter społecznych relacji wewnątrz grupy oraz ich psychologia społeczna. Wskazują oni wręcz na fakt, że takie cechy społeczno-psychologiczne jak ograniczenia poznawcze, ograniczone umiejętności naśladowania, apatia, i ogólny stan „psychicznego wyczerpania” (Roach \& Gursslin 1967, 387). wręcz uniemożliwiają tworzenie kultury jako takiej, gdyż ograniczają społeczne interakcje niezbędne do jej tworzenia i utrzymania. „Normy kulturowe, z definicji są normami grupowymi, które 
muszą być dodatkowo podtrzymywane przez transmisję za pomocą systemu skutecznej społecznej interakcji, obejmującego sieć jednostek rodzinnych oraz inne podstawowe grupy" (Roach \& Gursslin 1967, 388). Ubodzy zaś nie tworzą instytucji, organizacji, nie formują relacji, które w sposób świadomy miałyby przekazywać normy i wychowywać do kultury ubóstwa. Zdaniem autorów, jak i innych krytyków, ani jakość, ani ilość relacji podejmowanych przez większość ubogich opisywanych w badaniach empirycznych, nie kwalifikuje ich do tego typu interakcji społecznych, które są w stanie stworzyć i utrzymać kulturę. Nie wyklucza to jednak możliwości powstania pewnych charakterystycznych cech grupowych związanych ze sposobem życia, jak specyficzne preferencje w ubiorze czy wzory konsumpcyjne (Roach \& Gursslin, 387-389).

Roach i Gursslin nie odrzucili jednak całkowicie koncepcji kultury ubóstwa, wskazali raczej, że możliwe jest zaobserwowanie jej wśród wyizolowanych grup ubogich, których deprywacja materialna sięga kilku pokoleń. Są jednak sceptyczni wobec uznania uniwersalnej kultury dla wszelkich grup trwale ubogich. Ich zdaniem, bardziej stosowne jest mówienie o kilku rodzajach kultur ubóstwa, o odmiennych genezach i systemach przekazu międzypokoleniowego. Krytyka przez nich przedstawiona nie neguje istnienia rzeczonego zjawiska, jednak wskazuje na jego małą użyteczność w badaniach nad ubóstwem, ze względu na niewielką (proporcjonalnie do liczy osób, które można uznać za ubogie) grupę, która spełnia warunki, w jakich takie zjawisko może się wytworzyć. Z perspektywy pragmatyzmu prac nad ubóstwem rekomendują oni inne podejścia, na przykład „wyjaśnienie sytuacyjne” (situational explanation) Louisa Kriesberga (1963), które wyjaśnień dla specyficznych zachowań osób ubogich doszukuje się w strukturalnych i społecznych warunkach funkcjonowania, np. niskich zasobach finansowych, bezrobociu itd. Są to czynniki o większym stopniu uniwersalności, przez co teoria dotyczy większej ilości grup ubogich, nie jest też obciążona dodatkowymi problemami metodologicznymi, z jakimi boryka się „wyjaśnienie kulturowe”, np. pojęcie subkultury.

Dodatkowy problem pojawia się przy używaniu pojęć underclass i culture of poverty. Brak ich bardziej usystematyzowanych definicji i konsekwentnego stosowania. Bardzo często stosuje się je zamiennie, nie wprowadzając między nimi rozróżnień, co, moim zdaniem, jest błędnym podejściem. Gdybyśmy mieli ustalić relację obu pojęć, to teoria underclass byłaby nadrzędna względem kultury ubóstwa. Gdy posłużymy się chociażby definicją underclass zaproponowaną przez Mary Daly, zauważymy, że kultura ubóstwa jest jedną z cech wyróżniających podklasę. Daly postrzega underclass jako kategorię społeczną podlegającą marginalizacji społecznej i wykluczeniu przez dłuższy czas, doświadczającą deprywacji w różnych sferach życia, skupioną w zubożałych sąsiedztwach i charakteryzującą się podobieństwem kulturowym, które możemy określić jako kulturę ubóstwa (Daly 2001). Ta ostatnia jest więc jedną z cech charakterystycznych podklasy, cechą istotną, gdyż trudno jest sobie wyobrazić underclass bez odmiennych względem głównego nurtu elementów kulturowych. Podobnie w przypadku samej kultury ubóstwa, powinna być ona rozpatrywana głównie w kontekście podklasy i warunków, które jej 
wykształcenie wymaga.

Podsumowując można powiedzieć, że kultura ubóstwa związana jest z transferem międzypokoleniowym norm, wartości, wzorów zachowań i postaw życiowych. Są one wytworem (najczęściej wynikiem adaptacji do sytuacji) ludzi żyjących w specyficznych warunkach strukturalnych, społecznych i psychicznych. Gdy zostanie wytworzona, stanowi dodatkowy czynnik obciążający dla osób z kręgu biedy, gdyż w wyniku jej odmienności i nieakceptowania przez pozostałą część społeczeństwa (przeważanie oceniana jest jako kultura dewiacyjna, a osoby z kręgu kultury ubóstwa obwiniane są za swoje trudne położenie) realizacja ogólnych (dominujących w całym społeczeństwie) celów kulturowych, realizacja ról społecznych czy wartości, jest dla osób ubogich utrudniona. Warunki strukturalne w połączeniu z kulturq̨ ubóstwa ograniczają możliwości zmiany sytuacji życiowej, a procesy przekazu międzypokoleniowego dodatkowo ją utrwalają. Również mechanizm wykluczenia i izolacji, w następstwie których interakcje z osobami spoza kręgu biedy są ograniczone, przyczyniają się do utrwalania tejże kultury. Im bardziej zamknięta społeczność, tym silniej utrwala elementy swojej kultury, które w wyniku swoistej izolacji kontrastują wobec kultury głównego nurtu.

Autorka starała się przeprowadzić powyższą analizę na tyle wnikliwie, aby unaocznić, że underclass to pojęcie określające stan wyjątkowy tj. nader szczególny rodzaj doświadczenia ubóstwa, który najwyraźniej też uwidacznia wpływ ubóstwa na zdolność do wykształcenia stosownych kompetencji moralnych i społecznych warunkujących skuteczne funkcjonowanie we współczesnych społeczeństwach demokratycznych. Zygmunt Bauman postrzega podklasę jako „piętno totalnego wykluczenia ze wszystkich miejsc i sytuacji, w których tworzone są, negocjowane, przetwarzane i uchylane wszelkie inne ludzkie tożsamości oraz tytuły do uznania. Stan totalnego wykluczenia w wyniku strącenia do rzędu 'podklasy' oznacza bycie odartym ze wszystkich wytwarzanych w wymiarze społecznym i społecznie akceptowanych oznak i wyróżników, które podnoszą nagie życie biologiczne do rangi bytu społecznego, a tłum do rangi wspólnoty. Podklasa nie jest li tylko brakiem wspólnoty - to zupełna niemożność wspólnoty. Ostatecznie oznacza to także niemożność człowieczeństwa - tylko bowiem za pomocą sieci wspólnoty, dysponujących i respektowanych tożsamości można dostąpić człowieczeństwa. Jak blisko dwa i pół tysiąca lat temu wskazał Arystoteles, nie sposób być człowiekiem - bądź też, będąc człowiekiem, nie sposób przeżyć - poza polis; jedynie bogowie i zwierzęta potrafią żyć poza polis, dodał. Sokrates zapewne to zdanie podzielał, gdyż nie będąc ani bogiem, ani zwierzęciem, wolał czarę cykuty niż porzucenie na zawsze Aten" (Bauman 2012, 171).

Oczywiście włączenie trwale ubogich osób do pełnej partycypacji społecznej wymaga szeregu czynników. Pośród nich istotnym, a często niedocenianym elementem są stosowne kompetencje społeczne i moralne, pozwalające jednostkom na prawidłowe funkcjonowanie w różnych kontekstach, różnych grupach społecznych, z zachowaniem ich wymogów, co pozwala na realizację celów w ramach tych grup, a także umożliwia włączenie jednostki w jej ramy. Bez stosownych umiejętności społecznych ubodzy nie 
mają możliwości stać się pełnoprawnymi członkami społeczeństwa. Dlatego też w pracy tej podkreśliliśmy aspekt relacji ubóstwa i możliwości kształtowania kompetencji społecznych i moralnych.

\section{Literatura}

Argyle M. 2002. Psychologia stosunków międzyludzkich, przeł. W. Domachowski. Warszawa: PWN,

Auletta K. 1982. The Underclass. New York: Random House.

Bauman Z. 2012. Straty Uboczne. Nierówności społeczne w epoce globalizacji. Kraków: WUJ.

Bourdieu P. 2005. „Struktury, habitus, praktyki”, w: P. Sztompka \& M. Kucia (red.), Socjologia. Lektury. Kraków: Wydawnictwo Znak (546-58).

Bourdieu P. 2007. Szkic teorii praktyki poprzedzony trzema studiami na temat etnologii Kabylów, przeł. W. Krokier. Kęty: Antyk.

Braithwaite L. 1957. "Sociology and Demographic Research in the British Caribbean." Social and Economic Studies 6(4):523-71.

Braithwaite L. 1960. "Social Stratification And Cultural Pluralism." Annals of the New York Academy of Sciences 83:816-836.

Buckingham A. 1999. "Is the There an Underclass in Britain?" The British Journal of Sociology 50 (1):49-75.

Dahrendorf R. 1993. Nowoczesny konflikt społeczny. Warszawa: Czytelnik.

Daly M. 2001. Care Work: The Quest for Security. Geneva: International Labour Office.

Davis A. 1946. "The Motivation of the Underprivileged Worker", w: V. F. Whyte (Ed.), Industry and Society. New York: McGraw-Hill.

Della Fave L. R. 1974. "The Culture of Poverty Revisited: A Strategy for Research." Social Problems 21:609-621.

Domańska L. 2002. Deprywacja potrzeb byłych pracowników państwowych przedsiębiorstw gospodarki rolnej. Toruń: Uniwersytet Mikołaja Kopernika.

Domański H. 2002. Ubóstwo w społeczeństwach pokomunistycznych. Warszawa: Instytut Spraw Publicznych.

Duncan G., \& Brooks-Gunn J. (Eds.) 1997. Consequences of Growing Up Poor. New York: Russel Sage Foundation.

Duncan G. \& Brooks-Gunn J. 1998. "How Much Does Childhood Poverty Affect the Life Chances of Children?" American Sociological Review 30:491-498.

Erol R. \& Sawhill I. 1988. „Defining and Mesuring Underclass.” Journal of Policy, Analysis and Managment 7:316-325. 
Gallie D. 1988, “Employment, Unemployment and Social Stratification”, w: D. Gallie (Ed.), Employment in Britain. Oxford: Blackwell (465-92).

Gallie D. 1994. "Are the Unemployed an Underclass? Some Evidence from the Social Change in Economic Life Initiative." Sociology 28:737-57.

Giddens A. 2001. Poza lewicq i prawicq. Przyszłość polityki radykalnej. Poznań: Zysk i S-ka.

Goodwin L. 1972. Do the Poor Want to Work? A Social- Psychological Study of Work Orientations. Washington D.C.: Brooking Institution.

Grotowska-Leder J. 2004. „Underclass - kategoria teoretyczna i przedmiot działań praktycznych", w: K. Wódz \& K. Piątek (red.), Socjologia i polityka społeczna a aktualne problemy pracy socjalnej. Dylematy teorii i praktyki społecznej. Toruń: Wydawnictwo Edukacyjne Akapit (233-251).

Gudaszewski G. \& GUS 2015. Struktura narodowo-etniczna, językowa i wyznaniowa ludności Polski. Warszawa: Departament Badań Demograficznych i Rynku Pracy. Źródło: https://stat.gov.pl/files/gfx/portalinformacyjny/pl/ defaultaktualnosci/5670/22/1/1/struktura_narodowo-etniczna.pdf, dostęp dn. 12.09.2018.

Hannerz U. 1969. Soulside: Inquiries into Ghetto Culture and Community. Stockholm: Almquist \& Wiksell.

Harrington M. 1962. The Other America. Poverty in the United States, New York: Macmillan.

Hemmerling K. \& Scharlipp M. 2013. „The Keys of Cognition: Insights into Moral and Democratic Education in Prison", w: E. Nowak, D. E. Schrader, \& B. Zizek (Eds.), Educating Competencies for Democracy. Frankfurt/Main - Bern - Bruxelles - New York: Peter Lang Publishing (287-304).

Hemmerling K., Scharlipp M., \& Lind G. 2009. "Dyskusja Konstancka jako metoda edukacyjna w grupach wysokiego ryzyka", w: K. M. Cern, P. W. Juchacz, \& E. Nowak (red.), Etyka życia publicznego. Poznań: CoOpera, Wydawnictwo Naukowe IF UAM.

Hymati H. H. 1953. "The Value Systems of Different Classes: A Social Psychological Contribution to the Analysis of Stratification", w: R. Bendix \& S. M. Lipset (Eds.), Class, Status and Power. Glencoe: Free Press (426-42).

Jencks Ch. 1989. "What Is the Underclass - And Is It Growing?” Focus 12(1):14-26.

Johnson N. J. \& Sanday R. 1971. "Subcultural Variations in An Urban Poor Population.” American Anthropologist 73:128-43.

Karwacki A. 2006. Błędne Koło. Reprodukcja kultury podklasy społecznej, Toruń: Wydawnictwo Naukowe Uniwersytetu Mikołaja Kopernika.

Kohlberg L. 1964. “Development of Moral Character and Moral Ideology”, w: M. L. Hoffman \& L. W. Hoffman (Eds.), Review of Child Development Research, Vol. I, New York: Russel Sage Fundation. 
Kohlberg L. 1976. "Moral Stages and Moralization: The Cognitive-Developmental Approach", w: T. Lickona (Ed.), Moral Development and Behavior: Theory, Research, and Social Issues. New York: Holt.

Kołakowski L. 1988. Główne nurty marksizmu. Powstanie - rozwój - rozkład. Londyn: Aneks.

Korzeniowska K. \& Tarkowska E. (red.). 2002. Lata tłuste, lata chude... Spojrzenie na biedę w społecznościach lokalnych. Warszawa: IFiS PAN.

Kostyłło P. 2008. Wykluczenie jako problem filozofii edukacji. Kraków: Oficyna Wydawnicza Impuls.

Kraczla R. 1993. "Badania nad ubóstwem. Przegląd głównych nurtów i teorii”, w: K. Wódz (red.), W kręgu ubóstwa. Próba analizy psychospołecznych aspektów zjawiska. Katowice: Wydawnictwo UŚ.

Kriesberg L. 1963. "The Relationship between Socio-Economic Rank and Behavior." Social Problems 10(4):334-53.

Lee P. 1994. "Housing and Spatial Deprivation: Relocating the Underclass and the New Urban Poor." Urban Studies 31:1191-209.

Lewis 0. 1973. Sanchez i jego dzieci. Autobiografia rodziny meksykańskiej, przeł. A. Frybesowa. Warszawa: PIW.

Lewis O. 1969. "The Culture of Poverty", w: D. P. Moynihan (Ed.), On Understanding Poverty: Perspectives from the Social Sciences." New York: Basic Books.

Lewis 0. 1963. "The Culture of Poverty." Society 35:7-9.

Marshall G., Roberts S., \& Burgoyne C. 1996. "Social Class and Underclass in Britain and the USA." The British Journal of Sociology 47(1):22-44.

Martowska K. 2012. Psychologiczne uwarunkowania kompetencji społecznych, Wydawnictwo Liberi Libri. Źródło: http://liberilibri.pl/ksiazka/psychologiczneuwarunkowania-kompetencji-spo\%C5\%82ecznych-0, dostęp dn. 05.04.2014.

Mayer S. 1997. What Money Can't Buy. Family Income and Children's Life Chances. Cambridge, Mass.: Harvard Univ. Press.

Merton R. K. 2002. Teoria socjologiczna i struktura społeczna, przeł. E. Morawska, J. Wertenstein-Żuławski. Warszawa: PWN.

Miller S. M., Reissman D., \& Seagull A. 1971. "Poverty and Self-Indulgence: A Critique of the Non-Deferred Gratification Pattern", w: L. Ferman et al. (Eds.), Poverty in America. Ann Arbor: University of Chicago Press.

Morris L. 1994. Dangerous Classes: The Underclass and Social Citizenship. London: Routledge.

Murray Ch. 2001. Bez korzeni, przeł. P. Kwiatkowski. Poznań: Zysk i S-ka.

Niedzielski E. \& Kisiel R. (red.) 2001. Środowisko popegeerowskie - diagnoza stanu. Olsztyn: Uniwersytet Warmińsko-Mazurski - AWRSPO.

Parsons T. 1969. Struktura społeczna a osobowość, przeł. M. Tabin. Warszawa: Państwowe Wydawnictwo Ekonomiczne. 
Pearson L. J. 2003. "Understanding the Culture of Poverty." The Nurse Practitioner 28(4):6.

Poławski P. 1977. „Kulturowe znaczenie underclass. Spór o sens terminu a polska transformacja”, w: K. W. Frieske (red.), Ofiary sukcesu. Zjawiska marginalizacji społecznej w Polsce. Warszawa: IS UW.

Rainwater L. 1970. Behind Ghetto Walls. Chicago: Aldine.

Rainwater L. 2006. Behind Ghetto Walls: Black Family Life in a Federal Slum. New York: Transaction Publishers.

Rainwater L. 1967, The Problem of Lower-Class Culture and Poverty-War Strategy. Washington, D.C.: Washington University Press

Roach J. L. \& Gursslin O. R. 1967. "An Evaluation of the Concept ,Culture of Poverty'.” Social Forces 45(3):383-92.

Roach J. L. \& O. R. Gursslin O. R. 1965. “The Lower Class, Status Frustration and Social Disorganization." Social Forces 43(4):501-10.

Rodman H. 1963. "The Lower-Class Value Stretch." Social Forces 42(2):205-15.

Savage M., Devine F., Cunningham N., Li Y., Taylor M., Hjellbrekke J., Le Roux B., Friedman S. \& Miles A. 2013. "A New Model of Social Class: Findings from the Great British Class Survey Experiment." Sociology 47(2):219-50.

Schneiderman L. 1964. "Value Orientation Preferences of Chronic Relief Recipients." Social Work 9:13-18.

Smith D. J. 1992. Understanding the Underclass. London: Policy Studies Institute.

Smith R. T. 1956. The Negro Family in British Guiana. London: Routledge \& Kegan Paul.

Sykes G. M. \& Matza D. 1957. "Techniques of Neutralization: A Theory of Delinquency.” American Sociological Review 22:664-70.

Taft D. R. 1950. Criminology. Revised edition. New York: Macmillan.

Tarkowska E. 1999. „In Search of an Underclass in Poland.” Polish Sociological Review 125:3-16.

Tarkowska E. 2000. Zrozumieć biednego. O dawnej i obecnej biedzie w Polsce. Warszawa: Typografika.

Weber M. 2002. Gospodarka i społeczeństwo, przeł. D. Lachowska. Warszawa: PWN.

Westergaard J. 1992. "About and Beyond the 'Underclass': Some Notes on Influences of Social Climate on British Sociology Today." Sociology 26(4):575-87.

William R. 1971. Blaming the Victim. New York: Pantheon Books.

Wilson W. J. 1989. "Social Research and the Underclass Debate." Bulletin of the American Academy of Arts and Sciences 43(2):30-44.

Wilson W. J. 1989. "The Underclass: Issues, Perspectives, and Public Policy." Annals of the American Academy of Political and Social Science 501:182-92.

Wilson W. J. 1987. The Truly Disadvantaged. Chicago: Chicago University Press.

Wilson W. J. 1990, The Truly Disadvantaged: The Inner City, the Underclass, and Public Policy. Chicago: University of Chicago Press. 
Underclass i kultura ubóstwa w badaniach nad rozwojem kompetencji moralnych i społecznych w środowiskach ludzi ubogich

Wilson W. J. 1991. “Studying Inner-City Social Dislocations: The Challenge of Public Agenda Research." American Sociological Review 56:1-14.

Wódz K. 1994. „Underclass w starych dzielnicach przemysłowych miast Górnego Śląska", w: I. Machaj \& J. Styk (red.), Stare i nowe struktury społeczne w Polsce, t. I. Lublin: UMCS.

Wright E. O. 1997. Class Counts: Comparative Studies in Class Analysis, Cambridge: Cambridge University Press.

Zabielska J. M. 2007. Ubóstwo a procesy marginalizacji społecznej. Lublin: Wydawnictwo KUL. 


\title{
Karolina Kowalewska \\ (Poznań) \\ Underclass, Culture of Poverty and the Research \\ in Sociomoral Competence among the Poor
}

\begin{abstract}
In this paper, I consider whether a theoretically defined concept of underclass can be helpful in social scientific discourse. I analyze, review and categorize the concept of a underclass and I made some suggestions for a use of the concept application in the study of social, psychological and moral consequences of poverty. It begins with a discussion of the continuing and pervasive appeal of structural explanations as the root cause of poverty. Then are also examined cultural theories, which by contrast find explanation for poverty in various elements of culture (ex. cultural traits of poor are thought to be different from those of the rest society). A third, a synthetic review of the urban underclass concept is explored. The article also describes the concept of a "culture of poverty” (taking into account the context of the subculture) and "lower class value stretch" as influential concepts in analyses of contemporary poverty and in explanations of the behavior of the poor.
\end{abstract}

Keywords: underclass; culture od poverty; morality; value stretch; contemporary society.

Ethics in Progress (ISSN 2084-9257). Vol. 9 (2018). No. 1, Art. \#4, pp. 62-98.

Creative Commons BY-SA 3.0

Doi: 10.14746/eip.2018.1.4 